\title{
Do the changes in energy balance that occur during pregnancy predispose parous women to obesity?
}

\author{
H. E. Harris ${ }^{1}$ and G. T. H. Ellison ${ }^{2}$ \\ 'Maternal and Child Health Research Programme, University of Greenwich, Wellington Street, \\ London, SE18 6PF, United Kingdom. ${ }^{2}$ Institute for Behavioural Sciences, University of South \\ Africa, P.O. Box 392, Pretoria 0001, South Africa. Fax: +44181 3318305
}

Email: 101572.2635@Compuserve.com

\begin{abstract}
The aim of this review was to re-assess whether the changes in energy balance that accompany pregnancy predispose parous women to obesity. A number of crosssectional studies have sought to answer this question by examining the relationship between parity and maternal body weight. However, these studies were unable to control for the large number of sociobehavioural confounders that might be responsible for the apparent effect of parity on body weight. Longitudinal studies that examine changes in maternal body weight before and after pregnancy avoid these problems by using each mother as her own control. Nevertheless, these studies have to overcome three methodological constraints: They must obtain an accurate measure of prepregnant body weight, they must give each mother sufficient time to lose any weight retained following delivery, and they must take into account the effect of ageing on maternal weight gain during pregnancy and the follow-up period. More than $90 \%$ of the studies reviewed found body weight to be greater after pregnancy than it was before (by $0.2-10.6 \mathrm{~kg}$ ), and previous researchers who have examined the evidence for pregnancy-related weight gains suggest that body weight increases by an average of $0.4-4.8 \mathrm{~kg}$ following pregnancy. However, only three of the 71 longitudinal studies examined in the present review complied with the three methodological criteria. These studies concluded that mothers gain, on average, $0.9-3.3 \mathrm{~kg}$ more weight following pregnancy than nonpregnant controls, and that mean body weight remained 0.4 $3.0 \mathrm{~kg}$ higher, even after controlling for a number of sociobehavioural confounders. This apparently modest increase in mean maternal body weight for women having one or two children conceals the fact that some mothers experience a substantial increase in body weight and become obese following pregnancy. It remains unclear whether these increases are simply the result of changes in energy metabolism during pregnancy and lactation, or whether they are influenced by inherent changes in lifestyle that accompany pregnancy and motherhood. Understanding the relative importance of these alternatives might help to explain the aetiology of maternal obesity.
\end{abstract}

"Clover was a stout motherly mare approaching middle life, who had never quite got her figure back after her fourth foal"

George Orwell (1945) Animal Farm. London: Secker and Warburg. 


\section{Introduction}

In its simplest form, energy balance can be defined as the difference between energy intake and energy expenditure (James \& Schofield, 1990). Energy intake is determined by the quantity and energy density of ingested food, and the efficiency with which this food can be digested and utilized. Energy expenditure is determined by the amount of energy used to support basal metabolism, thermoregulation, digestion and physical activity. When changes in energy intake and/or expenditure result in a net change in energy balance, any surplus or deficit is reflected by the amount of energy deposited in, or removed from, body stores (Garrow, 1987). Because changes in the size of the body's energy stores inevitably cause changes in body weight, changes in body weight can be used to evaluate overall energy balance (Milne et al. 1991).

In practice, using changes in body weight to evaluate changes in energy stores represents an oversimplification, because changes in body weight can also reflect changes in body composition and fluid balance that occur without any change in energy balance. This is particularly relevant during pregnancy, when substantial changes in extracellular volume and body composition occur which create changes in body weight (Sohlström \& Forsum, 1995) that are usually interpreted as changes in fetal tissue and maternal energy reserves (Hytten, 1990a). Nevertheless, the pattern of maternal weight gain during pregnancy also reflects the changes in energy intake and/or energy expenditure that place a pregnant woman in positive energy balance (Hytten, 1990b).

It has been suggested that an increase in energy intake, mediated by enhanced appetite (Rosso, 1987) may be responsible for the weight gained during pregnancy. However, others (e.g. Durnin et al. 1985) suggest that increased energy intake is insufficient to account for the changes in energy balance that occur during pregnancy. Indeed, inadequate energy intake during pregnancy can result in the depletion of maternal energy stores (Winkvist et al. 1992) and net weight loss following delivery (Chowdhury, 1987). Nevertheless, several studies have shown that women are capable of supporting a successful pregnancy with a smaller increase in reported energy intake than that required to cover the estimated maintenance costs and costs of tissue accretion during pregnancy (Durnin et al. 1985; Hytten, 1990c). These studies indicate that a variety of physiological and behavioural adaptations may take place which help to improve energy efficiency during pregnancy and reduce the overall cost thereof (King et al. 1994). For example, Illingworth et al. (1987) found that pregnant women display a reduction in postprandial energy expenditure which might reflect more efficient digestion and/or absorption of food. Poppitt et al. (1993) described a reduction in basal metabolic rate and an improvement in the efficiency of exercise during pregnancy among rural Gambian women which they interpreted as energy-sparing adaptations. Similar women also display an apparent decline in core body temperature during the latter half of pregnancy (Whitehead et al. 1986) which would reduce the amount of energy required for thermoregulation.

The same changes in basal metabolism (Durnin et al. 1985; Prentice et al. 1989; Goldberg et al. 1993; King et al. 1994), thermoregulation (Clapp, 1991) and energy expenditure during exercise (Clapp, 1989) have been observed in well nourished pregnant women from developed countries who also tend to be less active during pregnancy (Dibblee \& Graham, 1983; Durnin et al. 1985; Clissold et al. 1991). This might explain why they display an increase in maternal body weight over and above that required for the growth of the fetus, placenta and other products of conception. Indeed, women from Scandinavia, Western Europe and North America who experience healthy, uncomplicated pregnancies enter motherhood with $2-10 \mathrm{~kg}$ of additional fat stores (King et al. 1949; see Table 1). Even in the past, when weight gain during pregnancy was restricted (as in the studies reviewed by Chesley, 1944), women were $1 \cdot 7-2 \cdot 2 \mathrm{~kg}$ 


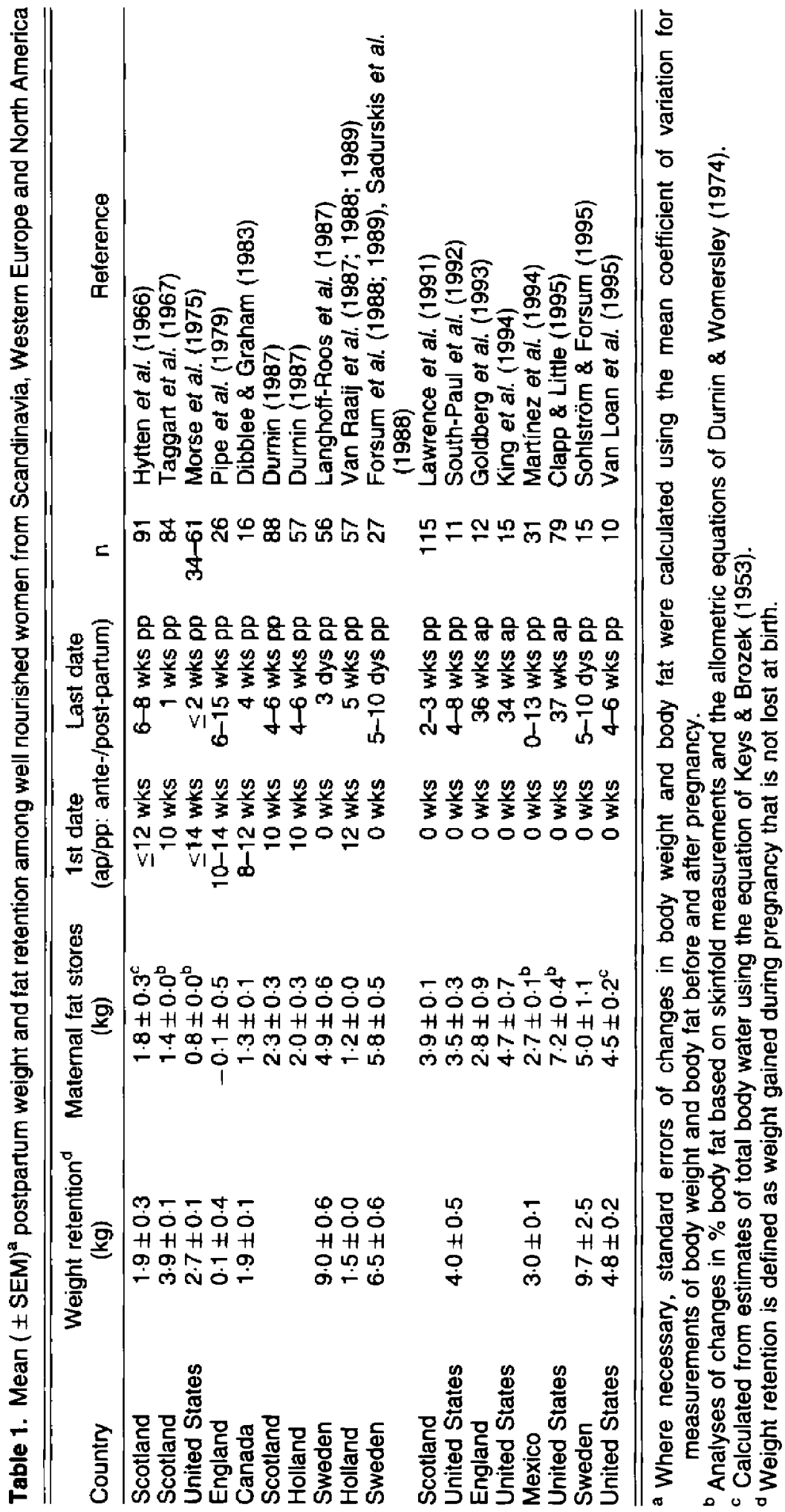


heavier at 6 weeks postpartum than they were prior to pregnancy. However, to a large extent, the weight gains experienced by these women are simply the result of an increased energy intake and a decline in the amount of energy expended on activity, because energy-sparing metabolic adaptations are comparatively modest, and occur more often in thin or malnourished women (Poppitt et al. 1994). In affluent societies, women who are underweight are less likely to gain weight during pregnancy (Harris et al. 1996) while in impoverished communities, women who are underweight are least likely to be capable of increasing their energy intake. It is therefore not surprising that energy-sparing adaptations are much more common among women from developing countries (Poppitt et al. 1994) who can be faced with a decline in energy intake and an increase in agricultural activity while they are pregnant (Prentice et al. 1981). Under these circumstances, energy sparing adaptations offset the cost of pregnancy and enable women to experience successful pregnancies with little or no weight gain (Prentice et al. 1987), although inadequate weight gains are also associated with suboptimal birth weights and a depletion of maternal energy reserves (Chowdhury, 1987; Winkvist et al. 1992).

In an evolutionary context, the accumulation of additional energy stores during pregnancy might have had distinct advantages when the availability of food to support fetal growth (Hytten, 1990b) and lactation (Whitehead et al. 1986) was unpredictable. Indeed, a similar argument has been proposed to explain why women have larger fat reserves than men (Garrow, 1987). However, well nourished women living in modern industrialized societies have little need for extensive fat reserves to guard against food shortages (Hytten, 1990a). Under these circumstances maternal fat deposits might be viewed simply as a "redundant evolutionary hangover" from less favourable times (Hytten, 1990a). As early as 1862, Gassner (cited by Stander \& Pastore, 1940) recognized that pregnant women tend to gain more weight than that required for the products of conception. In 1942 Waters was able to demonstrate that a large proportion of this additional weight was not lost during the puerperium, and by 1949 it was suggested that it was "a matter of common observation that women may ... develop a severe obesity after having a baby" (Sheldon, 1949). Undoubtedly, the view that pregnancy can lead to excessive weight gain has been widely held for some time (Gurney, 1936; Greene, 1939), and in 1978 Bray included pregnancy as one of four potential endocrinological causes in his aetiological classification of obesity. Not surprisingly, overweight mothers often cite pregnancy as the root cause of their obesity (Gurney, 1936; Mullins, 1960; James \& Bisdee, 1982; Bradley, 1985; Abraham, 1989; Lean et al. 1989; Öhlin \& Rössner, 1990), and weight gain during pregnancy has become an increasing concern for women who want to avoid obesity and regain a fashionable, slim figure after they have had children (Baric \& MacArthur, 1977; Feigenberg \& Schiller, 1977; Orr \& Simmons, 1979; Harrison \& Hicks, 1983; Palmer et al. 1985; Dawes et al. 1992; Franko \& Walton, 1993). These concerns are exacerbated by the recent guidelines of the United States Institute of Medicine (1990), which recommended higher weight gains during pregnancy than previously (Committee on Maternal Nutrition, 1970; AAP/ ACOG, 1983; see Table 2), and may increase the risk of weight retention post partum (Abrams, 1993; Keppel \& Taffel, 1993; Parker \& Abrams, 1993). Although no such guidelines exist in the UK, authoritative bodies such as the British Nutrition Foundation (1994) and the National Dairy Council (1994) have reproduced the weight gain guidelines published by the US Institute of Medicine (1990), and it is likely that these recommendations have some influence on antenatal care within the UK. In view of the importance currently attached to the high prevalence of obesity amongst women in North America (National Institutes of Health, 1985) and Europe (Millar \& Stephens, 1987; Department of Health, 1992) a clearer understanding of what effect, if any, pregnancy has on long-term maternal weight gain is urgently required 
Table 2. Recommended ranges for gestational weight gain, by prepregnancy Body Mass Index

\begin{tabular}{|c|c|c|}
\hline Recommendations & ACOG† (1985) & $\mathrm{IoM}_{+}^{+}(1990)$ \\
\hline Prepregnant BMI (kg.m $\left.\mathrm{m}^{-2}\right)$ & Weight gain in $\mathrm{kg}(\mathrm{lb})$ & Weight gain in $\mathrm{kg}(\mathrm{lb})$ \\
\hline $\begin{array}{l}\text { Low }(\mathrm{BMI}<19.8) \\
\text { Normal }(\mathrm{BMI} 19.8-26.0) \\
\text { High }(\mathrm{BMI}>26.0 \text { to } 29.0) \\
\text { Obese }(\mathrm{BMI}>29.0)\end{array}$ & $\begin{array}{l}>11.3(25)^{\star} \\
9.1-11.3(20-25) \\
<9.1(20)^{\star} \\
<9.1(20)^{\star}\end{array}$ & $\begin{array}{l}12.5-18.0(28-40) \\
11.5-16.0(25-35) \\
7.0-11.5(15-25) \\
>6.0(15)\end{array}$ \\
\hline
\end{tabular}

* Based on Taylor's (1971) recommendation that underweight women should be allowed to gain more weight than women of normal weight and that obese women should be allowed to diet and lose weight.

+ American College of Obstetricians and Gynecologists.

$\ddagger$ United States Institute of Medicine.

(Manson et al. 1994). The aim of this review will be to re-examine the evidence that pregnancy predisposes parous women to obesity.

\section{Reviewing the literature}

The studies examined in this review were obtained by a MEDLINE (US National Library of Medicine, Silver Platter International, NV) literature search extending back through 1995 to 1985 using the following paired key words: 'Pregnancy' and 'Obesity'; 'Pregnancy' and 'Body weight'; 'Pregnancy' and 'Weight gain'. Any publications that examined the relationship between maternal body weight and parity, or the pattern of maternal weight gain during and after pregnancy, were selected. These publications were subsequently reviewed and backreferenced until no further relevant papers could be found. This exhaustive survey should have identified any study containing suitable data for examining the effect of pregnancy on longterm changes in maternal body weight.

\section{Methodological considerations}

The changes in energy balance which accompany pregnancy are natural phenomena that are most appropriately investigated using case-control studies. These would examine the effect of pregnancy on maternal body weight by comparing the postpartum body weight of pregnant women with the body weight of matched, non-pregnant controls. Indeed, the first systematic studies were based on demographic and industrial surveys of women's body weight, such as those conducted by: the Industrial Fatigue Research Board (Cathcart et al. 1927), United States Department of Agriculture (1941), the Ministry of Food (Kemsley, 1950), Lowe \& Gibson (1955), and the Joint Clothing Council (Karn, 1957). These surveys found that women with children had a higher body weight than those without, and that maternal body weight increased with increasing parity (Fig. 1a). A similar cross-sectional design was used by 21 of the studies identified in the present review (Table 3). All but four (Lee-Feldstein et al. 1980; Prentice et al. 1981; Chowdhury, 1987; Kumanyika, 1987) of these studies observed an increase in maternal body weight with parity, and two of these four took place among undernourished rural 

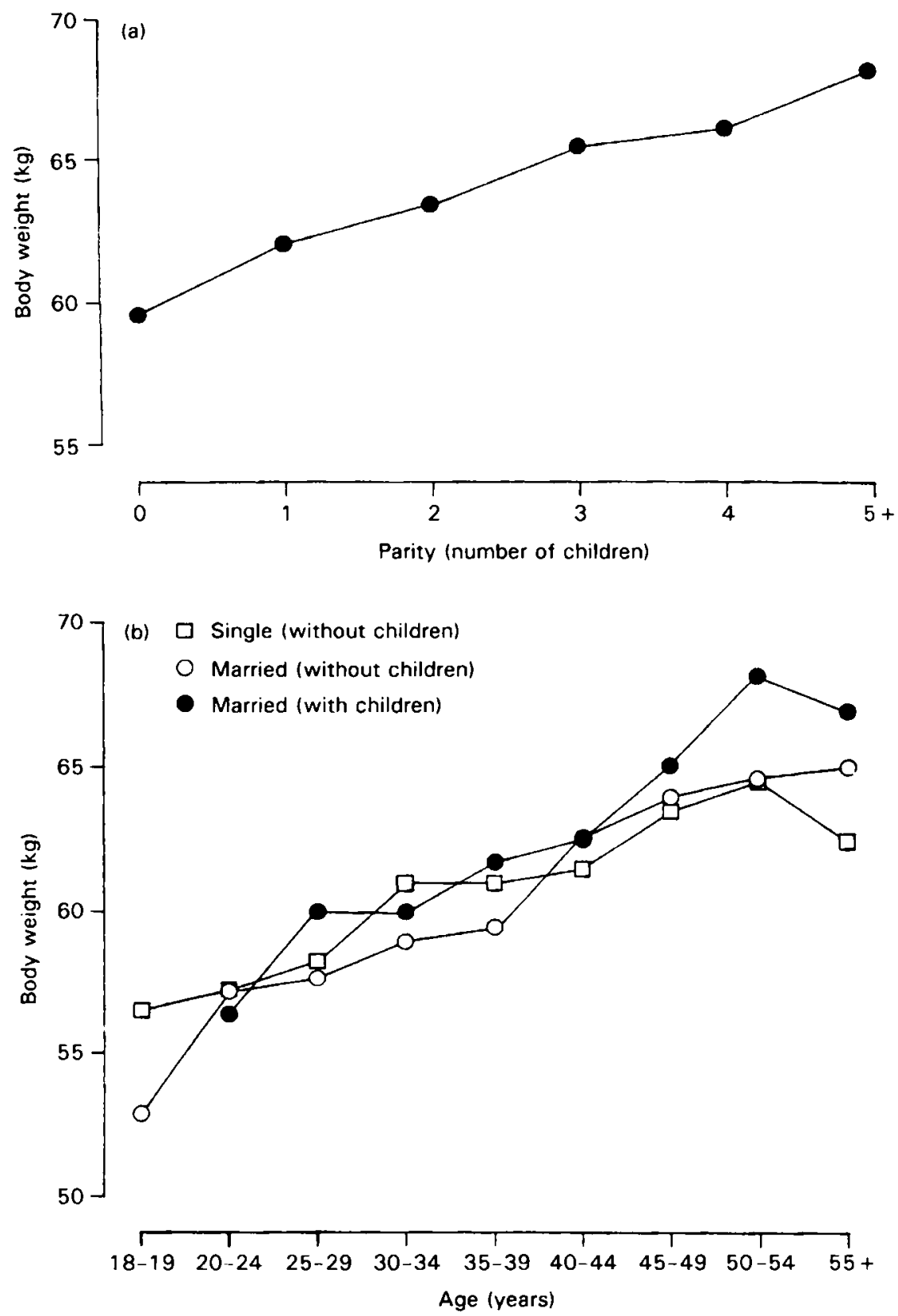

Fig 1. (a) The relationship between parity (number of children) and body weight among married women examined by the Joint Clothing Council in 1957. (b) The relationship between age, marital status and body weight among nulliparous and parous women examined by the Joint Clothing Council in 1957. 


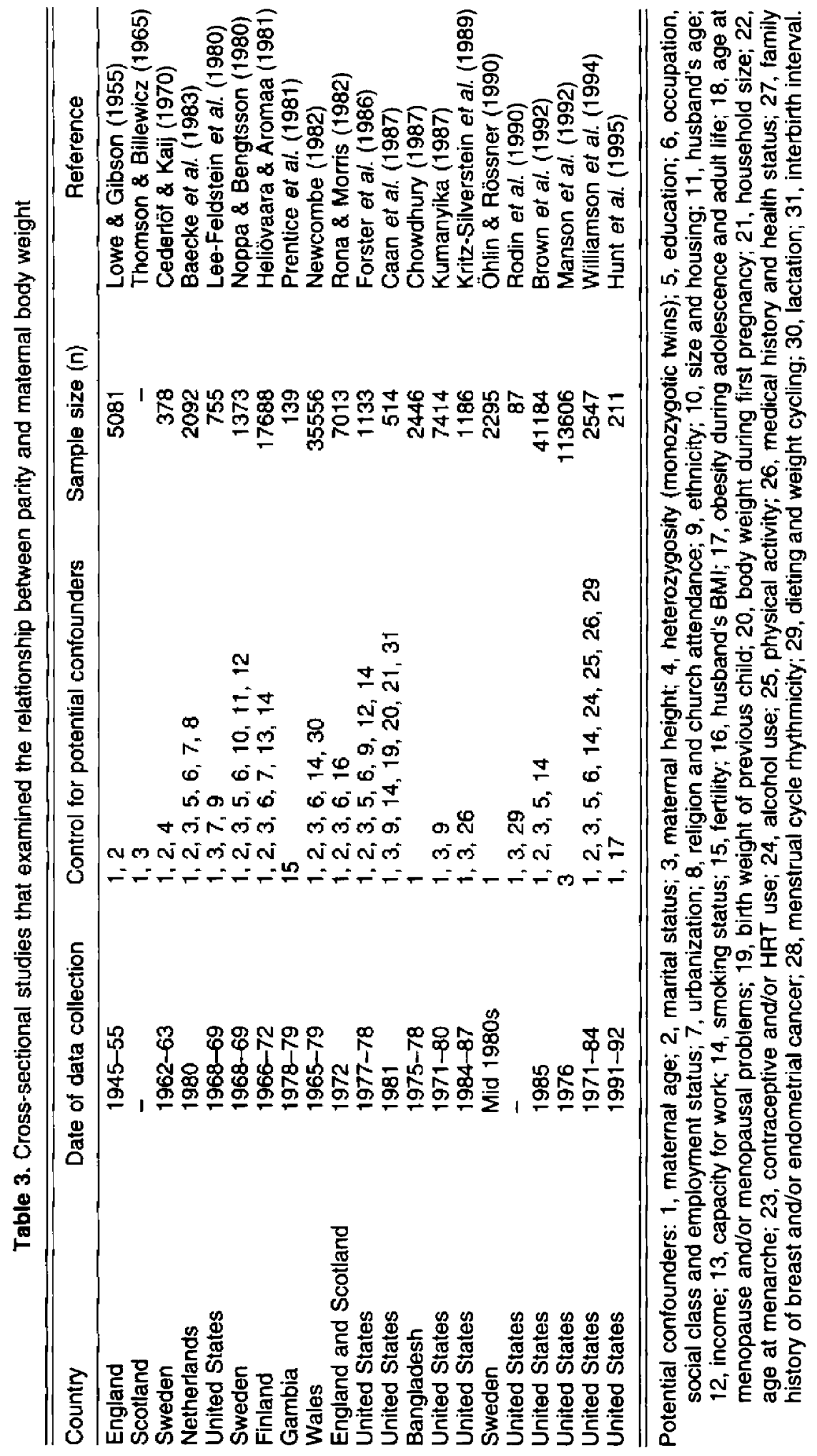


communities in developing countries (The Gambia, Prentice et al. 1981; Bangladesh, Chowdhury, 1987). However, parity is associated with a number of sociodemographic characteristics, such as higher maternal age, lower social class and marriage, that are independently associated with an increased risk of weight gain (Karn, 1957; Knight, 1984; Millar \& Stephens, 1987; Flegal et al. 1988; Kahn et al. 1991). Using the information on maternal age and marital status collected by the Joint Clothing Council (1957) to examine the independent effect of age, marriage and parity (see Fig. $1 b$ ), it is clear that the relationship between parity and maternal body weight (Fig. la) was largely the result of confounding (see Fig. $1 b$ ). Most of the studies listed in Table $3(19 ; 90.5 \%)$ attempted to control for confounding by taking into account differences in maternal age between mothers of differing parity. Others controlled for marital status $(10 ; 47.6 \%)$, social class $(7 ; 30.4 \%)$ and a number of additional factors (such as smoking cessation, see Table 3 ) that are known to be associated with higher weight gain (Gordon et al. 1975; Williamson et al. 1991). Although this approach reduces the possibility that any remaining differences in body weight between women of differing parity are simply the result of confounding, it is probably not feasible to control for all of the factors that might be responsible for differences in energy balance. At the same time, there might be inherent, immeasurable, and therefore uncontrollable differences between women who choose to have one or more child and those who have none. Even the study by Cederlöf \& Kaij (1970), which eliminated the effect of genetic characteristics (Sørensen \& Stunkard, 1993) by comparing the body weight of parous and nulliparous monozygotic twins, could not control for differences in attitudes towards motherhood, body image and weight gain between different twin sisters which might have influenced body weight (Strang \& Sullivan, 1985; Copper et al. 1995). Similar inherent differences might ultimately mask or create an apparent relationship between parity and body weight. For this reason, cross-sectional studies are inappropriate for investigating the role of pregnancy in the development of maternal obesity.

An alternative approach would be to conduct longitudinal studies and use pregnant women as their own controls by comparing their postpartum body weight with that recorded prior to pregnancy. Any differences in body weight could then be directly attributed to events that occurred during the intervening period. To assess whether persistent changes in maternal body weight occur, and whether pregnancy might be responsible for any of the changes observed, these longitudinal studies must satisfy three important criteria:

(i) they must obtain an accurate measure of prepregnant body weight;

(ii) they must give each mother enough time to lose any weight retained after the birth of their child;

(iii) they must take into account any increase in maternal body weight that would normally occur with age.

\section{The accurate measurement of prepregnant body weight}

In practice, prepregnant measures of maternal body weight are rarely available because most pregnancies are unplanned, and mothers are not routinely weighed before they conceive. Nevertheless, a few prospective studies have obtained accurate measurements of prepregnant body weight by recruiting women who were trying to become pregnant (e.g. Forsum et al. 1988, 1989; South-Paul et al. 1992; Goldberg et al. 1993; Van Loan et al. 1995). Unfortunately, these studies tend to have small sample sizes $(n=10-27)$ and include women who are likely to be unrepresentative of the population as a whole. A number of longitudinal studies (such as 
NHANES I and the CARDIA study) have managed to avoid these problems by collecting body weight data from large, representative samples of non-pregnant women, some of whom become pregnant and give birth during the period of follow-up (Rookus et al. 1987; Kusin et al. 1992; Smith et al. 1994; Williamson et al. 1994). However, for retrospective studies there is no alternative but to use self-reports of prepregnant weight or measurements of maternal weight recorded early in pregnancy. Although self-reports of body weight tend to underestimate true body weight (Palta et al. 1982; Stewart, 1982; Rössner \& Öhlin, 1995), those studies that used self-reported weights before and after pregnancy (e.g. Greene et al. 1988; Rössner, 1992; Keppel \& Taffel, 1993; Parker \& Abrams, 1993; Hunt et al. 1995) should provide a fairly accurate measure of maternal weight gain, because the effect of under-reporting should cancel out. But for those studies that used self-reports of prepregnant weight and measurements of maternal body weight post partum, under-reporting of prepregnant weights would tend to overestimate the amount of weight gained following pregnancy (see Fig. 2). These studies might also create the impression that overweight and obese women, who are particularly prone to under-reporting their body weight (Palta et al. 1982; Stewart, 1982; Stevens-Simon et al. 1992), gain more weight following pregnancy than normal and underweight women (Öhlin \& Rössner, 1990; Parham et al. 1990; Boardley et al. 1995). The only remaining option for studies that lack a direct measure of prepregnant body weight is to use a measurement of maternal weight collected early in pregnancy. Since the 1940s mothers have been routinely weighed during pregnancy (Scott \& Benjamin, 1948; Hytten, 1981, 1990a), yet most women only attend antenatal care after 8-12 weeks gestation (Kotelchuck, 1994; Sikorski et al. 1996), by which time they have usually gained some weight (Forsum et al. 1988; Van Raaij et al. 1989; Clapp, 1991). For this reason, any studies that use maternal weight measurements recorded early in pregnancy tend to overestimate prepregnant body weight, and underestimate the amount of weight gained as a result of pregnancy (see Fig. 2).

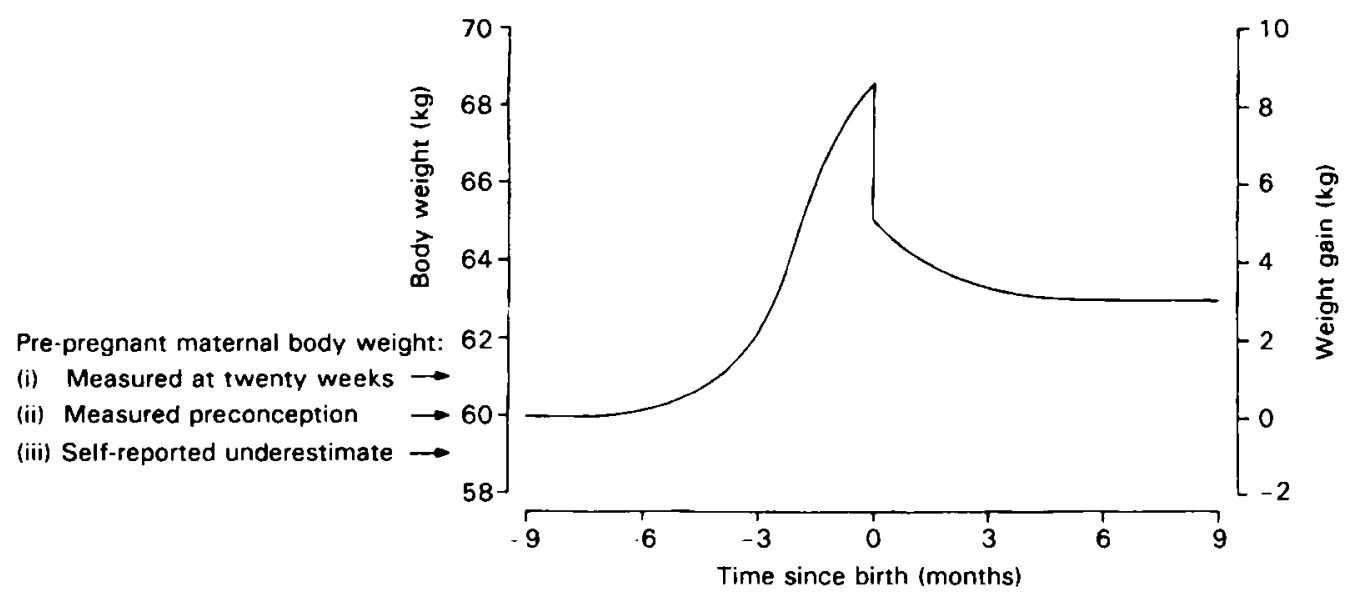

Fig 2. The effect of over- and under-estimating prepregnant body weight on calculations of long-term maternal weight gain. In this hypothetical example maternal weight measured at 20 weeks gestation (i) was $1 \mathrm{~kg}$ higher than that measured preconception (ii) and produced an underestimate of long-term weight gain at $2 \mathrm{~kg}$. Self-reported underestimates of prepregnant body weight (iii) were $1 \mathrm{~kg}$ less than that measured preconception (ii) and produced an overestimate of long-term weight gain at $4 \mathrm{~kg}$. 
The amount of time required to lose any weight retained following pregnancy

In the short term, it appears that most well nourished women gain weight as a result of pregnancy because they enter motherhood with $2-10 \mathrm{~kg}$ of additional fat stores (Table 1 ). In the long term, however, there is no theoretical reason why mothers should not mobilize these fat stores and return to their prepregnant body weight, provided they are given enough time to do so. Any studies that weigh mothers before they have had time to lose the fat gained during pregnancy are likely to conclude that pregnancy causes a permanent increase in maternal body weight. These studies need to give each woman sufficient time to lose any weight retained following the birth of their child before assessing whether permanent changes in body weight have occurred. This methodological constraint applies as much to the cross-sectional studies examined in Table 3 as it does to longitudinal studies of maternal weight gain following pregnancy. Nevertheless, only 2 of the 21 studies examined in Table 3 excluded parous women who had recently given birth, and 10 even failed to assess whether the women were currently pregnant.

In theory, the amount of time required to lose any excess weight retained post partum can be estimated by calculating its energy content and the amount of time required to use up this energy. In this review, net maternal weight gain during pregnancy (the amount of weight gained during pregnancy minus the baby's birth weight) was used to provide an estimate of the amount of weight retained following pregnancy (after Parham et al. 1990). This measure of retained weight included the weight of the placenta and amniotic fluids, together with any increase in maternal blood volume and lean body tissue that occurred during pregnancy (Sohlström \& Forsum, 1995). However, it was assumed that retained weight consisted entirely of maternal fat stores (Langhoff-Roos et al. 1987; Hytten, 1991) in order to provide an overestimate of the amount of energy contained therein and a conservative estimate of the amount of time required to use up this energy. Energy values were assigned to each mother's retained weight, taking the energy density of fat as $37000 \mathrm{~kJ} / \mathrm{kg}(8843 \mathrm{kcal} / \mathrm{kg}$ : James \& Schofield, 1990). Assuming that each mother adhered to a modest weight reducing diet of $7113 \mathrm{~kJ}(1700 \mathrm{kcal})$ per day (which is consistent with a steady weight loss of approximately $0.4-0.5 \mathrm{~kg}$ per week; Perri et al. 1992), and that these mothers required $9205 \mathrm{~kJ}$ (2200 kcal; non-lactating) to $11297 \mathrm{~kJ}(2700 \mathrm{kcal}$; lactating) per day (in accordance with the recommended daily allowance for energy; Murphy \& Abrams, 1993), they should have lost $2092-4184 \mathrm{~kJ}(500-1000 \mathrm{kcal})$ or $57-114 \mathrm{~g}$ of their retained weight per day. To illustrate this, Fig. 3 shows the hypothetical weight loss trajectories for women who retained different amounts of weight, when they were subject to different weight reducing diets. Theoretical weight retentions of 5 and $15 \mathrm{~kg}$ were selected since they approximate to the upper and lower limits of normal retained weight (Parham et al. 1990). A non-lactating woman who enters motherhood with a weight retention of $5 \mathrm{~kg}$ would take nearly 3 months to return to her prepregnant weight on a $7113 \mathrm{~kJ}(1700 \mathrm{kcal})$ diet (see Fig. 3 ), while non-lactating women who retain $15 \mathrm{~kg}$ would take nearly 9 months to do so on the same diet. Lactating women, with their higher energy requirements, would take just over 6 weeks to remove $5 \mathrm{~kg}$ of retained weight on a $7113 \mathrm{~kJ}(1700 \mathrm{kcal})$ diet, and nearly 4.5 months to mobilize $15 \mathrm{~kg}$. Indeed, even if they stopped eating altogether, non-lactating women would still need around 9 weeks to mobilize $15 \mathrm{~kg}$ of retained weight while lactating women would do so in just 7 weeks!

The increase in body weight with age during the study period

There is a tendency for maternal body weight to increase with age even in the absence of pregnancy (Colditz et al. 1990; Williamson et al. 1994). For this reason, studies of long-term 


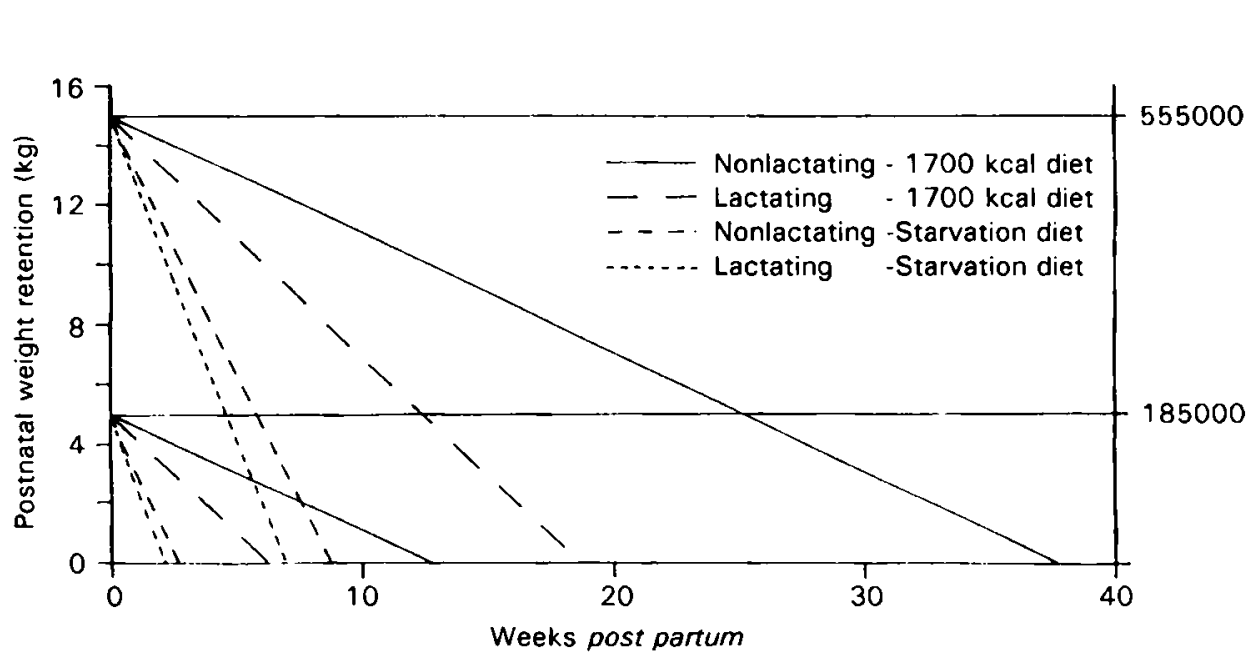

Fig 3. Hypothetical weight loss trajectories of mothers who retained $5 \mathrm{~kg}$ or $15 \mathrm{~kg}$ after the birth of their baby (Parham et al. 1990). Trajectories were calculated for women on both a $1700 \mathrm{kcal}$ weight reducing and a zero kcal starvation diet, assuming that non-lactating women require $2200 \mathrm{kcal}$ per day and lactating women require $2700 \mathrm{kcal}$ per day (Murphy \& Abrams, 1993).

changes in maternal body weight need to take into account the amount of weight mothers would normally gain had they not been pregnant. Contemporary estimates of ageing-related weight gain, for well nourished women of childbearing age, range from $0.29 \mathrm{~kg}$ to $0.96 \mathrm{~kg}$ per year (Colditz et al. 1990; Kuskowska-Wolk \& Rössner, 1990; Parham et al. 1990; Kahn et al. 1991; Klesges et al. 1992; Sowers et al. 1996). It is therefore extremely important to obtain an appropriate estimate of ageing-related weight gain for each individual woman. McKeown \& Record (1957) achieved this by recording maternal weight gain from 12 to 24 months post partum and subtracting this amount from the weight gained between conception and 12 months post partum. However, suitable data for calculating pre- or post-pregnant changes in matemal body weight are usually unavailable, and most studies are faced with two possibilities for controlling for the effect of ageing on maternal weight gain: they can either correct for differences in the duration of follow-up (e.g. Greene et al. 1988), or they can account for the amount of weight gained by similar, non-pregnant women during the same period of time (e.g. Öhlin \& Rössner, 1990; Parham et al. 1990). The first approach tends to undercontrol for the effect of ageing, because it fails to account for the effect of ageing on maternal weight gain during the period of pregnancy. The second approach suffers from the same limitations as the cross-sectional studies reviewed in Table 3, because any differences in the amount of weight gained by pregnant and non-pregnant women might simply be the result of confounding. Indeed, non-pregnant, nulliparous women tend to gain more weight than non-pregnant parous women (Williamson et al. 1994) which suggests that their tendency to gain weight may be related to their ability or decision to bear children (Zaadstra et al. 1993). Nevertheless, in some respects a cross-sectional analysis provides the most sensitive approach, because it can control for a number of behavioural changes that commonly occur during pregnancy (Clissold et al. 1991), such as smoking cessation (Williamson et al. 1991) and inactivity (Klesges et al. 1992), which might increase the risk of weight gain among women who experience pregnancy (see Öhlin \& Rössner, 1994). 


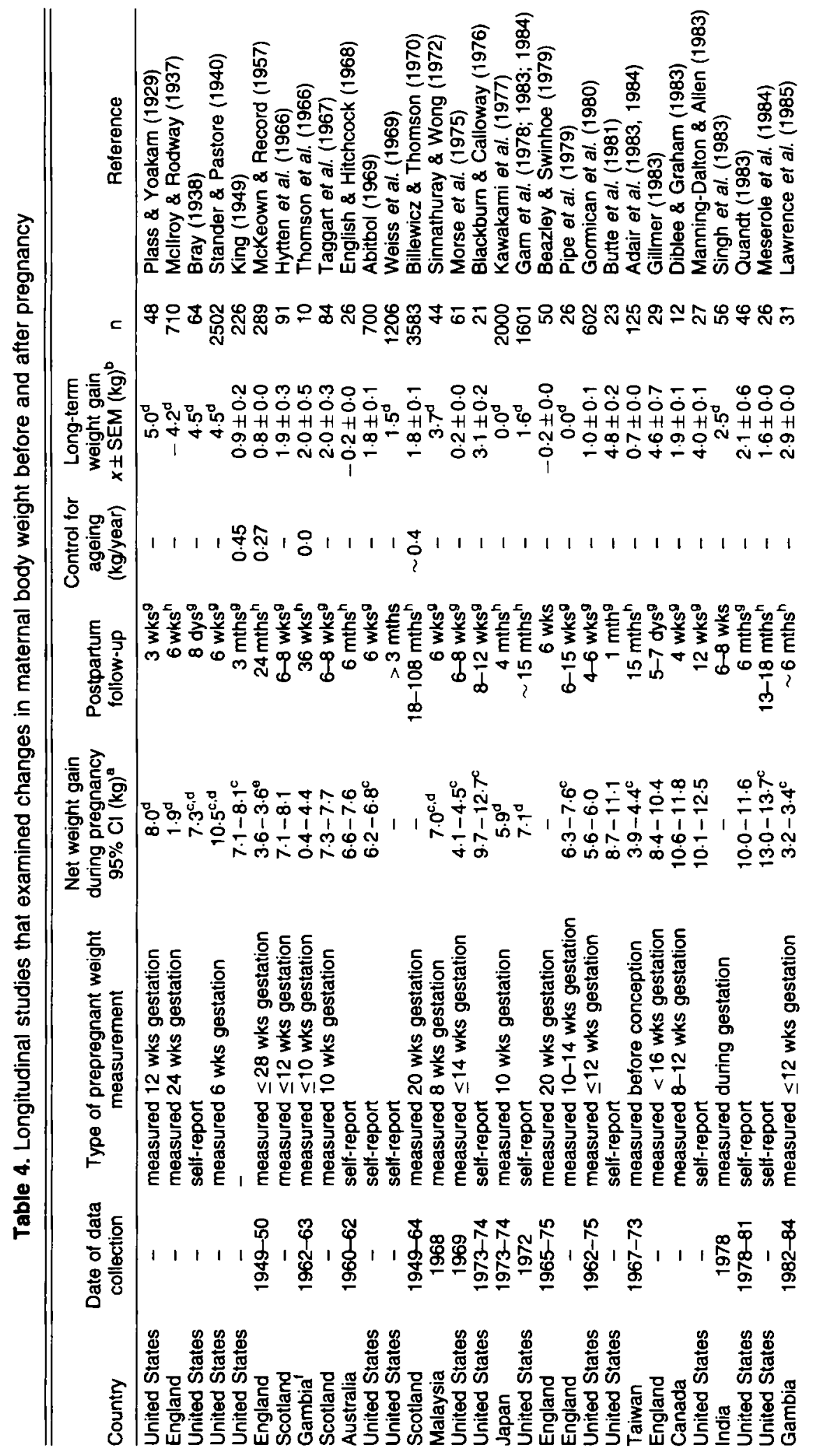




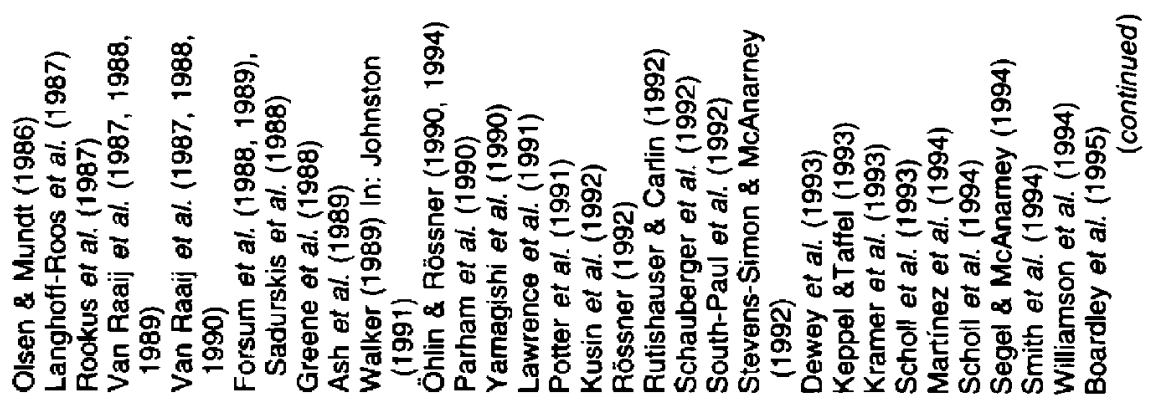

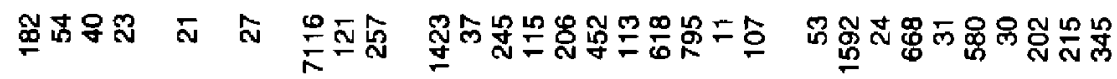

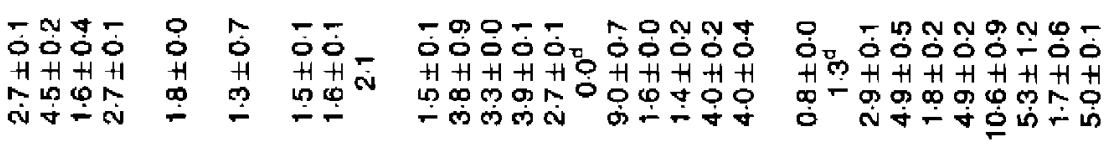

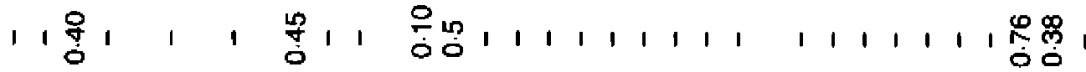

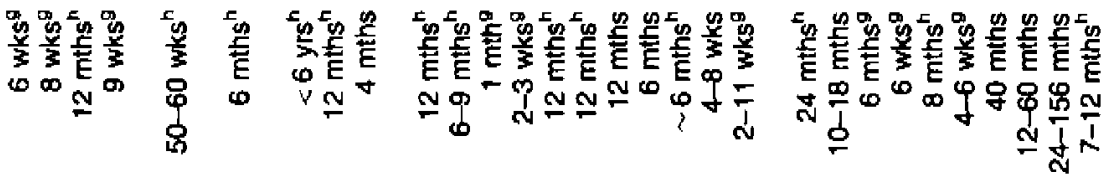

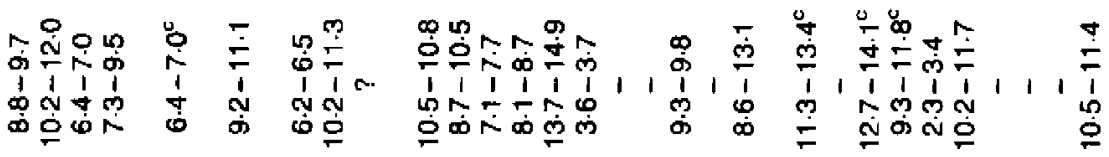

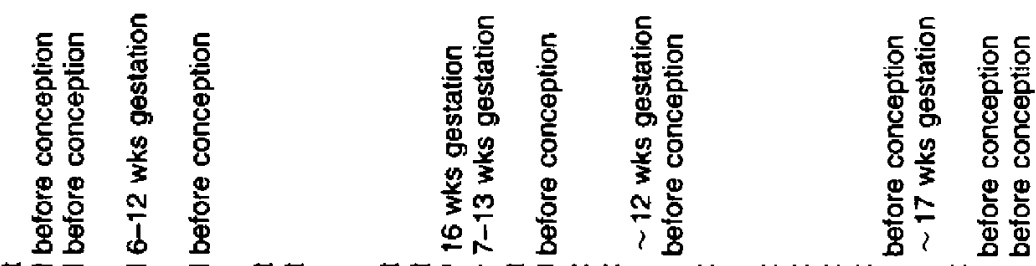

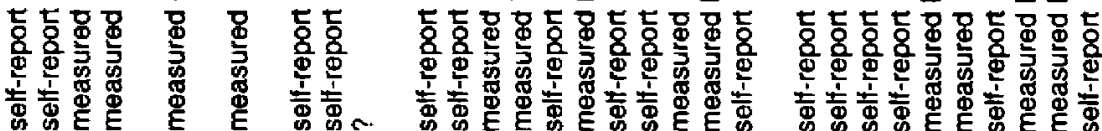

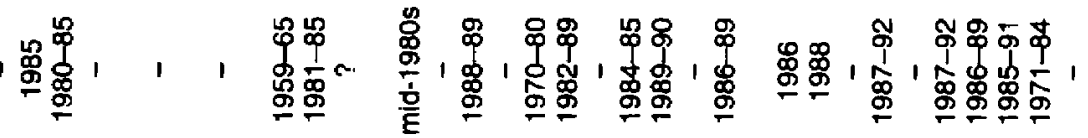

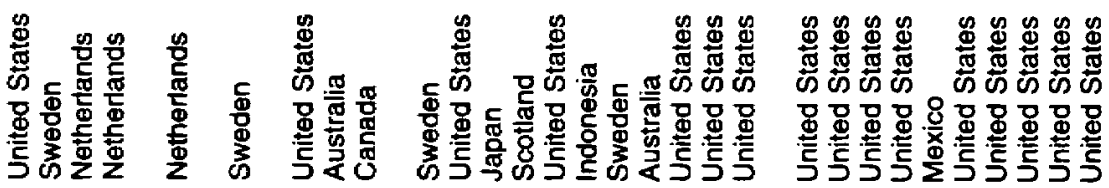




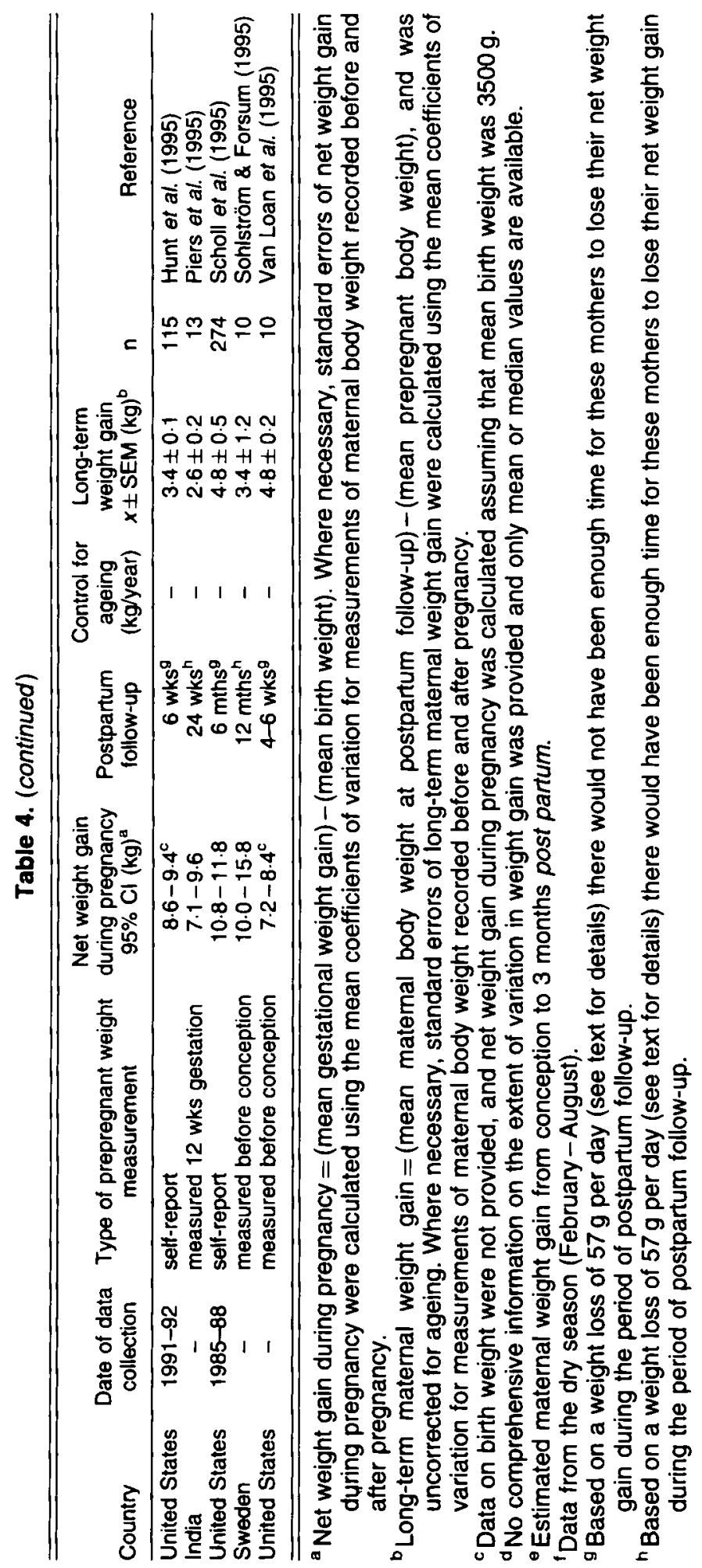




\section{Discussion}

The literature search identified a total of 71 longitudinal studies that examined maternal weight gain following pregnancy, although 6 of these studies (Sheldon, 1949; Prentice et al. 1981; Caan et al. 1987; Samra et al. 1988; Brown et al. 1992; Parker \& Abrams, 1993) gave no specific information regarding long-term weight gain following pregnancy. Salient methodological characteristics of the remaining 65 studies have been summarized in Table 4 , and the distribution of long-term weight gains indicated by these studies is shown in Fig. 4.

Fig. 4 clearly shows that most of the studies $(90.8 \%)$ found body weight to be greater after pregnancy than it was before. Only 6 of the studies (McIlroy \& Rodway, 1937; English \& Hitchcock, 1968; Kawakami et al. 1977; Beazley \& Swinhoe, 1979; Pipe et al. 1979; Kusin et al. 1992) showed no overall increase in body weight following pregnancy (see Fig. 4). However, 3 of these (McIlroy \& Rodway, 1937; English \& Hitchcock, 1968; Beazley \& Swinhoe 1979) were conducted at a time when clinicians routinely advocated weight restriction during pregnancy, which is notable since high gestational weight gain may be one of the most important risk factors for maternal obesity in developed countries (Greene et al. 1988; Keppel \& Taffel, 1993; Parker \& Abrams, 1993; Boardley et al. 1995; Rössner \& Öhlin, 1995; Scholl et al. 1995). One of the three remaining studies used women from a developing country where maternal depletion, rather than maternal obesity, was the norm (Indonesia: Kusin et al. 1992), and another study may have been unreliable by virtue of its small sample size $(\mathrm{n}=26$ : Pipe $e t$ al. 1979). At the other extreme, there were 2 studies that found pregnancy-related weight gains far in excess of $5.0 \mathrm{~kg}$ (9.0 kg: Rössner, 1992; $10.6 \mathrm{~kg}$ : Segel \& McAnarney, 1994). These studied sampled women who were of low socioeconomic status (Segel \& McAnarney, 1994) or who were obese (Rössner, 1992), both of which have been identified as risk factors for weight gain, irrespective of pregnancy (Schauberger et al. 1992; Stevens-Simon et al. 1992; Parker \& Abrams, 1993; Boardley et al. 1995).

Overall, the results of the 65 studies suggest that pregnancy-related weight gains vary greatly. However, only 11 of these 65 studies obtained accurate measures of maternal body weight prior to conception, while 21 used weight measurements recorded early in pregnancy (6-20 weeks gestation) and 27 used self-reports of prepregnant body weight. Likewise, the duration of follow-up ranged from 5 days (Gillmer 1983) to 156 months (Williamson et al. 1994). By calculating the upper $95 \%$ confidence intervals of net weight gain during pregnancy, and assuming a conservative weight loss of $57 \mathrm{~g}$ per day (as described above), it was possible to establish that fewer than half (25) of the 53 studies, with appropriate data on gestational weight gain, gave their subjects sufficient time to lose the weight retained after delivery. Similarly, only 10 studies corrected for the potential effect of ageing on weight gain during pregnancy and the follow-up period. To assess the effect of methodological differences on estimates of longterm weight gain, the studies contained in Table 4 were grouped according to the type of prepregnant weight measurement used and their long-term weight gain was plotted against the duration of postpartum follow-up (see Fig. 5). As expected, studies that used self-reports of prepregnant weights had higher estimates of long-term weight gain, while those using weight measurements recorded early in pregnancy had lower estimates of long-term weight gain. Studies that gave mothers insufficient time to lose the weight retained following delivery displayed an apparent decrease in long-term weight gain as the duration of follow-up increased. In contrast, those studies that gave mothers enough time to lose any retained weight displayed a slight increase in long-term weight gain over time, which reflects the effect of ageing.

Applying the three methodological criteria (an accurate measure of prepregnant weight, sufficient time to lose retained weight and control for ageing) to each of the studies examined in 


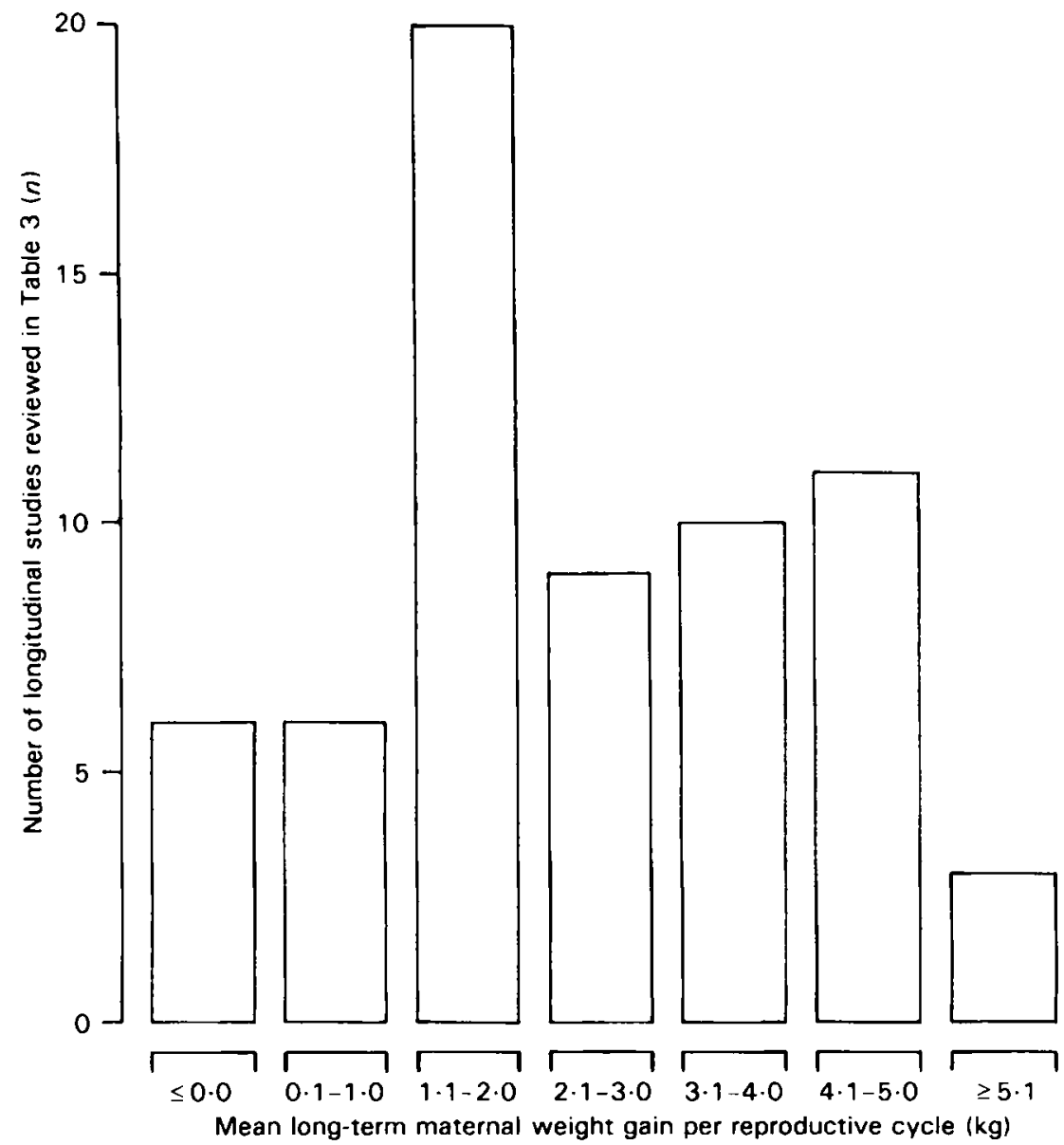

Fig 4. The distribution of mean long-term weight gains following pregnancy, as assessed by the longitudinal studies that examined changes in maternal body weight before and after pregnancy.

Table 4, just one (Rookus et al. 1987) appeared to comply with all three. Two additional studies (Smith et al. 1994; Williamson et al. 1994) failed to provide sufficient data to calculate net weight gain during pregnancy, although the duration of follow-up in both these studies ( $>12$ months) would have been sufficient to lose the highest amount of net weight gain observed (15.8 kg; Sohlström \& Forsum, 1995). These three methodologically sound studies suggest that average maternal weight gains range from $0.9 \mathrm{~kg}$ (Rookus et al. 1987) and $1.7 \mathrm{~kg}$ (Williamson et al. 1994) to $3.3 \mathrm{~kg}$ (Smith et al. 1994) over and above that gained by non-pregnant controls. However, these differences in weight gain were somewhat smaller $(0.4 \mathrm{~kg}$, Rookus et al. 1987 ; $0.6-3.0 \mathrm{~kg}$, Smith et al. 1994; 1.4-1.6 kg, Williamson et al. 1994) after accounting for a range of potential confounders. These included age, height, education, parity, giving up work and smoking status (Rookus $e$ t al. 1987), together with prepregnant body weight and activity (Smith et al. 1994) as well as alcohol consumption, marital status, morbidity and dieting behaviour (Williamson et al. 1994). 


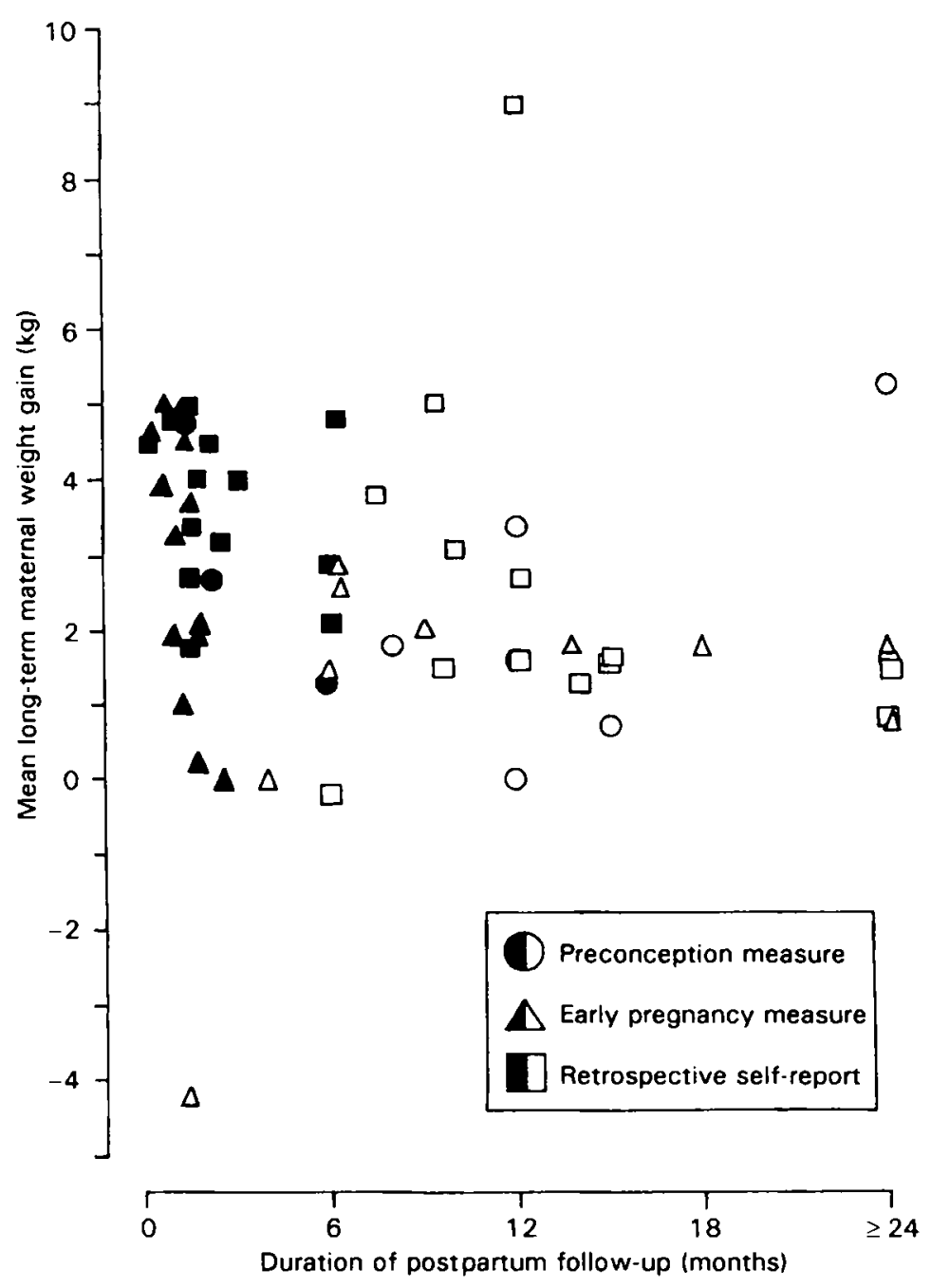

Fig 5. The relationship between mean long-term weight gain and the duration of postpartum follow-up for 65 longitudinal studies that examined changes in maternal body weight before and after pregnancy. Each study has been categorized according to the type of prepregnant weight measurement used $(0$, preconception measure; $\triangle$, early pregnancy measure, and $\square$, retrospective self-report) and whether the study gave their subjects sufficient time to lose any weight retained following delivery $(O, \square, \Delta)$ or not $(\Theta$, $\mathbf{\square}, \mathbf{\Delta})$.

Compared to previous reviews of maternal obesity (Johnston, 1991; Lederman, 1993; Crowell, 1995; Rössner \& Öhlin, 1995), our findings provide the most complete collection of studies and apply the most stringent methodological criteria. By comparison, Johnston (1991) asked whether pregnancy might lead to an increase in body weight over and above that expected as a result of ageing. She included a variety of studies dating from 1949 to 1990, but cited only 14 of the 42 studies listed in Table 4 that predate publication of her review, and 
Table 5. Methodological criteria of previous reviews which investigated the impact of pregnancy on long-term changes in maternal body weight

\begin{tabular}{|c|c|c|c|c|}
\hline Methodological Criteria & $\begin{array}{l}\text { Johnston } \\
1991\end{array}$ & $\begin{array}{l}\text { Lederman } \\
\quad 1993\end{array}$ & $\begin{array}{c}\text { Crowell } \\
1995\end{array}$ & $\begin{array}{c}\text { Rössner and Öhlin, } \\
1995\end{array}$ \\
\hline $\begin{array}{l}\text { 1. Accurate measure of } \\
\text { prepregnant } \quad \text { weight }\end{array}$ & $x$ & $\sqrt{ }$ & $x$ & $\sqrt{ }$ \\
\hline $\begin{array}{l}\text { 2. Sufficient time to lose any } \\
\text { retained weight }\end{array}$ & $x$ & $x$ & $x$ & $\sqrt{ }$ \\
\hline $\begin{array}{l}\text { 3. Correction for the weight gain } \\
\text { with ageing }\end{array}$ & $\sqrt{ }$ & $\sqrt{ }$ & $\sqrt{ }$ & $\sqrt{ }$ \\
\hline $\begin{array}{l}\text { 4. Risk factors for maternal } \\
\text { obesity discussed }\end{array}$ & $\sqrt{ }$ & $\sqrt{ }$ & $\sqrt{ }$ & $\sqrt{ }$ \\
\hline $\begin{array}{l}\text { 5. Number of studies cited } \\
\text { 6. Mean long-term maternal } \\
\text { weight gain per reproductive cycle } \\
\text { (kg) }\end{array}$ & $\stackrel{22}{0.5-4.8}$ & $\begin{array}{l}17 \\
<1.5\end{array}$ & $\begin{array}{l}15 \\
1.0\end{array}$ & $\begin{array}{c}12 \\
0.4-3.8\end{array}$ \\
\hline
\end{tabular}

summarized only the mean long-term weight gains for nine of these (see Table 5). Although the significance of inaccurate measures of prepregnant weight and insufficient time to lose weight retained following delivery were not discussed, she concluded that most studies show pregnancy to be associated with a modest overall increase in body weight. She also emphasized that both high gestational weight gain and an already high prepregnant weight are important risk factors for maternal obesity. In a similar way, Crowell (1995) reviewed studies over a ten year period from 1983 to 1993, and cited 14 of the 59 studies listed in Table 4 (see Table 5). She concluded that, on average, women tend to be about $1.0 \mathrm{~kg}$ heavier after pregnancy than they were before, after accounting for the increase in weight with ageing. Like Johnston (1991), she suggested that there are approximately 1 in 10 women at risk of excessive $(>6.6 \mathrm{~kg})$ pregnancy-related weight gains. Crowell's (1995) review focused on risk factors for maternal obesity. In particular, she concluded that those women who gain more than $15.7-18.0 \mathrm{~kg}$ during pregnancy are at greatest risk of maternal obesity. Other important risk factors discussed include high prepregnant weight, low socioeconomic status, smoking cessation, high parity, and ethnicity. Both Crowell (1995) and Johnston (1991) concluded that lactation has, at best, an inconsistent effect on weight change after delivery.

In contrast, Lederman (1993) challenged the 'widely held view' that many women increase their body weight permanently as a result of pregnancy. She also explored the determinants of postpartum weight retention using studies from the decade preceding publication of her review (see Table 5). Lederman (1993) extracted and synthesized data on gestational weight gains and postpartum weight changes to identify alternative explanations for weight changes that have been credited to pregnancy in the past. By reassessing existing studies, Lederman (1993) identified a variety of inappropriate assumptions made by past studies of maternal obesity, and demonstrated that ageing was a major determinant of the weight increases associated with parity in cross-sectional studies. She concluded that average pregnancy-related weight gains are generally less than $1.5 \mathrm{~kg}$ during a single reproductive cycle (before pregnancy to 1 year post partum), but that obese women have larger weight changes (both lower and higher) than lowerweight women. In addition, this review (Lederman, 1993) emphasizes that under-reporting of prepregnancy weight, particularly by overweight women, would tend to overestimate weight gained in association with pregnancy. Like Crowell (1995) and Johnston (1991), Lederman (1993) acknowledged that a small number of women increase weight greatly during a 
reproductive cycle, although the studies she reviewed do not prove that this weight gain is a direct result of pregnancy. For this reason Lederman (1993) suggested that the changes in lifestyle associated with pregnancy and motherhood, such as cessation of smoking, delayed return to work, depression, attitude to weight gain, and changes in body image, may be a more likely cause of maternal obesity than pregnancy itself. This conclusion was echoed by Rössner \& Öhlin (1995) who presented a summary of the findings and lessons learnt from the Stockholm Pregnancy and Weight Development Study (Öhlin \& Rössner, 1990, 1994; Rössner, 1992). In this review, Rössner \& Öhlin (1995) demonstrated that most cross-sectional studies showed an increase in body weight with parity that was independent of ageing, but suggested that, for the population generally, the effect of pregnancy on future weight development is often difficult to predict. Their own research showed that for women who develop obesity, pregnancy can be an important triggering life event, and their review of the literature provided an estimate of long-term maternal weight gain of $0.4-3.8 \mathrm{~kg}$ (see Table 5). Nevertheless, they identified a number of methodological criteria to be taken into account when evaluating the results of previous studies. (1) There are problems associated with uncertain measures of prepregnant weight. (2) They discuss the implications of when to determine postpregnancy body weight. (3) There is need to correct for the increase in body weight that would have occurred normally as a result of ageing. They also discuss the relevance of risk factors for maternal obesity, including gestational weight gain, cessation of smoking, and various other behavioural and sociodemographic factors (Öhlin \& Rössner, 1990, 1994) which explain some of the considerable variation in pregnancy-related weight gains that are observed.

In the present review pregnancy-related weight gains appear modest in mothers who experience only one or two pregnancies, yet they mask the fact that some mothers experience a substantial increase in body weight following pregnancy and mothers who have 3 or more pregnancies may accumulate more than $10 \mathrm{~kg}$ in weight. Whether these increases are simply the result of changes in energy balance during pregnancy and lactation (e.g. Illingworth et al. 1986; Prentice et al. 1989) or whether they are influenced by inherent changes in lifestyle that accompany pregnancy and motherhood (e.g. Leifer, 1977; Clissold et al. 1991) remains unclear. Understanding the relative importance of these alternatives might help to explain why most mothers gain little weight following pregnancy while some become obese (Sheldon, 1949).

\section{References}

Abitbol, M. M. (1969). Weight gain in pregnancy. American Joumal of Obstetrics and Gynecology 104, $140-157$.

Abraham, S. (1989). Problems with weight control during pregnancy. Medical Journal of Australia 151, 237.

Abrams, B. (1993). Prenatal weight gain and postpartum weight retention: a delicate balance. American Joumal of Public Health 83, 1082-1084.

Adair, L. S., Pollitt, E. \& Mueller, W. H. (1983). Matemal anthropometric changes during pregnancy and lactation in a - rural Taiwanese population. Human Biology 55, 771-787.

Adair, L. S., Pollitt, E. \& Mueller, W. H. (1984). The Bacon Chow study. Effect of nutritional supplementation on matemal weight and skinfold thicknesses during pregnancy and lactation. British Journal of Nutrition 51, 357-369.

AAP/ACOG (American Academy of Pediatrics \& American College of Obstetricians and Gynecologists) (1983). Guidelines for prenatal care. Elk Grove, IL: American Academy of Pediatrics.

Ash, S., Fisher, C. C., Truswell, A. S., Allen, J. R. \& Irwig, L. (1989). Maternal weight gain, smoking, and other factors in pregnancy as predictors of infant birth-weight in Sydney women. Australian and New Zealand Journal of Obstetrics and Gynaecology 29, 212-219.

Baecke, J. A. H., Burema, J., Frijters, J. E. R., Hautvast, J. G. A. J. \& Van der Weil-Wetzels, W. A. M. (1983). Obesity in young Dutch adults. I. Socio-demographic variables and body mass index. Intemational Joumal of Obesity 7 , $1-12$. 
Baric, L. \& MacArthur, C. (1977). Health norms in pregnancy. British Jourmal of Preventative and Social Medicine 31, 30-38.

Beazley, J. M. \& Swinhoe, J. R. (1979). Body weight in parous women: is there any alteration between successive pregnancies? Acta Obstetricia et Gynecologica Scandinavica 58, 45-47.

Billewicz, W. Z. \& Thomson, A. M. (1970). Body weight in parous women. British Journal of Preventative and Social Medicine 24, 97-104.

Blackburn, M. W. \& Calloway, D. H. (1976). Energy expenditure and consumption of mature, pregnant and lactating women. Journal of the American Dietetic Association 69, 29-37.

Boardley, D. J., Sargent, R. G., Coker, A. L., Hussey, J. R. \& Sharpe, P. A. (1995). The relationship between diet, activity, and other factors, and postpartum weight change by race. Obstetrics and Gynecology 86, 834-838.

Bradley, P. J. (1985). Conditions recalled to have been associated with weight gain in adulthood. Appetite 6, $235-241$.

Bray, G. A. (1978). Definition, measurement, and classification of the syndromes of obesity. International Joumal of Obesity 2, 99-112.

Bray, P. N. (1938). Weight changes in pregnancy. American Joumal of Obstetrics and Gynecology 35, $802-809$.

British Nutrition Foundation (1994). Nutrition in Pregnancy. London: British Nutrition Foundation.

Brown, J. E., Kaye, S. A. \& Folsom, A. R. (1992). Parity-related weight change in women. International Journal of Obesity 16, 627-631.

Butte, N. F., Calloway, D. H. \& Van Duzen, J. L. (1981). Nutritional assessment of pregnant and lactating Navajo women. American Joumal of Clinical Nutrition 34, 2216-2228.

Caan, B., Horgen, D. M., Margen, S., King, J. C. \& Jewell, N. P. (1987). Benefits associated with WIC supplemental feeding during the interpregnancy interval. American Journal of Clinical Nutrition 45, 29-41.

Cathcart, E. P., Bedale, E. M., Blair, C., Macleod, K. \& Weatherhead, M. (1927). The Physique of Women in Industry p. 44. London: Industrial Fatigue Research Board.

Cederlöf, R. \& Kaij, L. (1970). The effect of childbearing on body weight: a twin control study. Acta Psychiatrica Scandinavica, Suppl. 219, 47-49.

Chesley, L. C. (1944). Weight changes and water balance in normal and toxic pregnancy. American Journal of Obstetrics and Gynecology 48, 565-591.

Chowdhury, A. K. M. A. (1987). Changes in maternal nutritional status in a chronically malnourished population in rural Bangladesh. Ecology of Food and Nutrition 19, 201-211.

Clapp, J. F. (1989). Oxygen consumption during treadmill exercise, before, during, and after pregnancy. American Joumal of Obstetrics and Gynecology 161, 1458-64.

Clapp. J. F. (1991). The changing thermal response to endurance exercise during pregnancy. American Journal of Obstetrics and Gynecology 165, 1684-1689.

Clapp. J. F. \& Little, K. D. (1995). Effect of recreational exercise on pregnancy weight gain and subcutaneous fat deposition. Medicine and Science in Sports and Exercise 27, 170-177.

Clissold, T. L., Hopkins, W. G. \& Seddon, R. J. (1991). Lifestyle behaviours during pregnancy. New Zealand Medical Journal 104, 111-113.

Colditz, G. A., Willett, W. C., Stampfer, M. J., London, S. J., Segal, M. R. \& Speizer, F. E. (1990). Patterns of weight change and their relation to diet in a cohort of healthy women. American Joumal of Clinical Nutrition 51, 1100 1105.

Committee on Matemal Nutrition (1970). Matemal Nutrition and the Course of Pregnancy. Washington, DC: National Academy of Sciences.

Copper, R. L., DuBard, M. B., Goldenberg. R. L. \& Oweis, A. I. (1995), The relationship of maternal attitude toward weight gain to weight gain during pregnancy and low birth weight. Obstetrics and Gynecology 85, 590-595.

Crowell, D. T. (1995). Weight change in the postpartum period. A review of the literature. Journal of Nurse Midwifery 40, 418-423.

Dawes, M. G., Green, J. \& Ashurst, H. (1992). Routine weighing in pregnancy. British Medical Journal 304, 487-489.

Department of Health (1992). The Health of the Nation: A strategy for health in England. London: HMSO.

Dewey, K. G., Heinig, M. J. \& Nommsen, L. A. (1993). Maternal weight-loss patterns during prolonged lactation. American Joumal of Clinical Nutrition 58, 162-166.

Dibblee, L. \& Graham, T. E. (1983). A longitudinal study of changes in aerobic fitness, body composition, and energy intake in primigravid patients. American Journal of Obstetrics and Gynecology 147, 908-914.

Durnin, J. V. G. A. (1987). Energy requirements of pregnancy. An integration of the longitudinal data from the fivecountry study. Lancet ii, 1131-1134.

Durnin, J. V. G. A., McKillop, F. M., Grant, S. \& Fitzgerald, G. (1985). Is nutritional status endangered by virtually no extra intake during pregnancy? Lancet ii, 823-826.

Durnin, J. V. G. A. \& Womersley, J. (1974). Body fat assessed from total body density and its estimation from skinfold thickness. Measurements on 481 men and women aged from 16 to 72 years. British Journal of Nutrition 32, 77-97.

English, R. M. \& Hitchcock, N. E. (1968). Nutrient intakes during pregnancy, lactation and after the cessation of lactation in a group of Australian women. British Joumal of Nutrition 22, 615-624.

Feigenberg, M. \& Schiller, R. (1977). Nutritional counselling for middle class gravidas. Journal of Obstetric, Gynecological and Neonatal Nursing 6, 19-22.

Flegal, K. M., Harlan, W. R. \& Landis, J. R. (1988). Secular trends in body mass index and skinfold thickness with socioeconomic factors in young adult women. American Journal of Clinical Nutrition 48, 535-543. 
Forster, J. L., Bloom, E., Sorensen, G., Jeffery, R. W. \& Prineas, R. J. (1986). Reproductive history and body mass index in black and white women. Preventive Medicine 15, 685-691.

Forsum, E., Sadurskis, A. \& Wager, J. (1988). Resting metabolic rate and body composition of healthy Swedish women during pregnancy. American Joumal of Clinical Nutrition 47, 942-947.

Forsum, E., Sadurskis, A. \& Wager, J. (1989). Estimation of body fat in healthy Swedish women during pregnancy and lactation. American Journal of Clinical Nutrition 50, 465-473.

Franko, D. L. \& Walton, B. E. (1993). Pregnancy and eating disorders. A review and clinical implications. International Journal of Eating Disorders 13, 41-48.

Garn, S. M., La Velle, M., Pesick, S. D. \& Ridella, S. A. (1984). Are pregnant teenagers still in rapid growth? American Joumal of Diseases of Children 138, 32-34.

Garn, S. M. \& Petzold, A. S. (1983). Characteristics of the mother and child in teenage pregnancy. American Joumal of Diseases of Children 137, 365-368.

Garn, S. M., Shaw, H. A. \& McCabe, K. D. (1978). Effect of maternal smoking on weight and weight gain between pregnancies. American Journal of Clinical Nutrition 31, 1302-1303.

Garrow, J. S. (1987). Energy balance in man - an overview. American Joumal of Clinical Nutrition 45, 1114 1119.

Gillmer, M. D. G. (1983). Obesity in pregnancy - clinical and metabolic effects. In Nutrition in Pregnancy: proceedings of the tenth Study Group of the Royal College of Obstetricians and Gynaecologists, p. 213-230 [D. M. Campbell and M. D. G. Gillmer, editors]. London: RCOG.

Goldberg, G. R., Prentice, A. M., Coward, W. A., Davies, H. L., Murgatroyd, P. R., Wensing, C., Black, A. E., Harding, M. \& Sawyer, M. (1993). Longitudinal assessment of energy expenditure in pregnancy by the doubly labeled water method. American Journal of Clinical Nutrition 57, 494-505.

Gordon, T., Kannel, W. B., Dawber, T. R. \& McGee, D. (1975). Changes associated with quitting cigarette smoking: the Framingham Study. American Heart Joumal 90, 322-328.

Gormican, A., Valentine, J. \& Satter, E. (1980). Relationships of maternal weight gain, prepregnancy weight, and infant birth weight: Interaction of weight factors in pregnancy. Journal of the American Dietetic Association 77, $662-667$.

Greene, G. W., Smiciklas-Wright, H., Scholl, T. O. \& Karp, R. J. (1988). Postpartum weight change: how much of the weight gained in pregnancy will be lost after delivery? Obstetrics and Gynecology 71, 701-707.

Greene, J. A. (1939). Clinical study of the etiology of obesity. Annals of Internal Medicine 12, 1797-1803.

Gurney, R. (1936). The hereditary factor in obesity. Archives of Intermal Medicine 57, 557-561.

Harris, H. E., Ellison, G. T. H., Holliday, M. \& Lucassen, E. (1996). Identifying the possible causes of matemal obesity. Proceedings of the Nutrition Society 55, $231 \mathrm{~A}$.

Harrison, M. J. \& Hicks, S. A. (1983). Postpartum concerns of mothers and their sources of help. Canadian Journal of Public Health 74, 325-328.

Heliövaara, M. \& Aromaa, A. (1981). Parity and obesity. Journal of Epidemiology and Community Health 35, $197-199$.

Hunt, S. C., Daines, M. M., Adams, T. D., Heath, E. M. \& Williams, R. R. (1995). Pregnancy weight retention in morbid obesity. Obesity Research 3, 121-130.

Hytten, F. E. (1981). Weight gain in pregnancy - 30 years of research. South African Medical Journal 60, 15-19.

Hytten, F. (1990a). Is it important or even useful to measure weight gain in pregnancy? Midwifery 6, 28-32.

Hytten, F. (1990b). Nutritional requirements in pregnancy: what should the pregnant woman be eating? Midwifery 6 , 93-98.

Hytten, F. $(1990 \mathrm{c})$. Nutritional requirements in pregnancy: what happens if they are not met? Midwifery 6, 140-145.

Hytten, F. E. (1991). Weight gain in pregnancy. In Clinical Physiology in Obstetrics, 2nd edn, pp. 173-203 [F. Hytten and G. Chamberlain, editors]. Oxford: Blackwell.

Hytten, F. E., Thomson, A. M. \& Taggart, N. (1966). Total body water in normal pregnancy. Journal of Obstetrics and Gynaecology of the British Commonwealth 73, 553-561.

Illingworth, P. J., Jung, R. T., Howie, P. W. \& Isles, T. E. (1987). Reduction in postprandial energy expenditure during pregnancy. British Medical Joumal 294, 1573-1576.

Illingworth, P. J., Jung, R. T., Howie, P. W., Leslie, P. \& Isles, T. E. (1986). Diminution in energy expenditure during lactation. British Medical Journal 292, 437-441.

James, W. P. T. \& Bisdee, J. T. (1982). Energy balance in obesity and its relevance to pregnancy. In Nutrition in Pregnancy: proceedings of the tenth Study Group of the Royal College of Obstetricians and Gynaecologists, pp. 231241 [D. M. Campbell and M. D. G. Gillmer, editors]. London: RCOG.

James, W. P. T. \& Schofield, E. C. (1990). Human Energy Requirements: a manual for planners and nutritionalists. Oxford: Oxford Medical Publications.

Johnston, E. M. (1991). Weight changes during pregnancy and the postpartum period. Progress in Food and Nutrition Science 15, 117-157.

Joint Clothing Council (1957). Women's Measurements and Sizes. London: HMSO.

Kahn, H. S., Williamson, D. F. \& Stevens, J. A. (1991). Race and weight change in US women: the roles of socioeconomic and marital status. American Joumal of Public Health 81, 319-323.

Kam, M. N. (1957). Considerations arising from weight and some other vajables recorded in the survey of women's measurements. Annals of Human Genetics 22, 385-390.

Kawakami, S., Ishiwata, C., Hayashi, K., Kawaguchi, Y., Kondo, N. \& Iizuka, R. (1977). Alteration of maternal body weight in pregnancy and the postpartum. Keio Journal of Medicine 26, 53-62. 
Kemsley, W. F. F. (1950). Weight and height of a population in 1943. Annals of Eugenics 15, 161-183.

Keppel, K. G. \& Taffel, S. M. (1993). Pregnancy-related weight gain and retention: implications of the 1990 Institute of Medicine guidelines. American Joumal of Public Health 83, 1100-1 103.

Keys, A. \& Brozek, J. (1953). Body fat in adult man. Physiological Reviews 33, 245-325.

King, A. G. (1949). Free-feeding pregnant women. American Journal of Obstetrics and Gynecology 58, $299-307$.

King, J. C., Butte, N. F., Bronstein, M. N., Kopp, L. E. \& Lindquist, S. A. (1994). Energy metabolism during pregnancy: influence of matemal energy status. American Joumal of Clinical Nutrition 59, 439S-445S.

Klesges, R. C., Klesges, L. M., Haddock, C. K. \& Eck, L. H. (1992). A longitudinal analysis of the impact of dietary intake and physical activity on weight change in adults. American Journal of Clinical Nutrition 55. 818-822.

Knight, I. (1984). The Heights and Weights of Adults in Great Britain. London: HMSO, for Office of Population Censuses and Surveys.

Kotelchuck, M. (1994). The adequacy of prenatal care utilization index: its US distribution and association with low birthweight. American Joumal of Public Health 84, 1486-1489.

Kramer, F. M., Stunkard, A. J., Marshall, K. A., McKinney, S. \& Liebschutz, J. (1993). Breast-feeding reduces matemal lower-body fat. Journal of the American Dietetic Association 93, 429-433.

Kritz-Silverstein, D., Barretı-Connor, E. \& Wingard, D. L. (1989). The effect of parity on the later development of non-insulin dependent diebetes mellitus or impaired glucose tolerance. New England Joumal of Medicine 321. 1214-1219.

Kumanyika, S. (1987). Obesity in black women. Epidemiologic Reviews 9, 31-50.

Kusin, J. A., Kardjati, S., Renqvist, U. \& Goei, K. (1992). Reproduction and maternal nutrition in Madura, Indonesia. Tropical and Geographical Medicine 44, 248-255.

Kuskowska-Wolk, A. \& Rössner, S. (1990). Prevalence of obesity in Sweden. Cross-sectional study of a representative adult sample. Journal of Internal Medicine 227, 241-246.

Langhoff-Roos, J., Lindmark, G. \& Gebre-Medhin, M. (1987). Maternal fat stores and fat accretion during pregnancy in relation to infant birth weight. British Joumal of Obstetrics and Gynaecology 94, 1170-1177.

Lawrence, M., McKillop, F. M. \& Durnin, J. V. G. A. (1991). Women who gain more fat during pregnancy may not have bigger babies: implications for recommended weight gain during pregnancy. British Journal of Obstetrics and Gynaecology 98, 254-259.

Lawrence, M., Singh, J., Lawrence, F. \& Whithead, F. G. (1985). The energy cost of common daily activities in African women: increased expenditure in pregnancy. American Joumal of Clinical Nutrition 42, 753-763.

Lean, M. E. J., Sutherland, H. W. \& Garthwaite, P. (1989). Obesity and fat distribution. In Carbohydrate metabolism in pregnancy and the newborn, vol. IV. [H. W. Sutherland, J. M. Stowers and D. W. M. Pearson, editors]. London: Springer-Verlag.

Lederman, S. A. (1993). The effect of pregnancy weight gain on later obesity. Obstetrics and Gynecology 82, $148-155$.

Lee-Feldstein, A., Harburg, E. \& Hauenstein, L. (1980). Parity and blood pressure among four race-stress groups of females in Detroit. American Joumal of Epidemiology 111, 356-366.

Leifer, M. (1977). Psychological changes accompanying pregnancy and motherhood. Genetic Psychology Monographs 95, 55-96.

Lowe, C. R. \& Gibson, J. R. (1955). Changes in body weight associated with age and marital status. British Medical Joumal ii, 1006-1008.

Mcllroy, A. L. \& Rodway, H. E. (1937). Weight-changes during and after pregnancy with special reference to the early diagnosis of toxaemia. Joumal of Obstetrics and Gynaecology of the British Empire 44, 221-244.

McKeown, T. \& Record, R. G. (1957). The influence of reproduction on body weight in women. Journal of Endocrinology 15, 393-409.

Manning-Dalton, C. \& Allen, L. H. (1983). The effects of lactation on energy and protein consumption, postpartum weight change and body composition of well nourished North American women. Nutrition Research 3, 293-308.

Manson, J. E., Colditz, G. A. \& Stampfer, M. J. (1994). Parity, ponderosity, and the paradox of a weight-preoccupied society. Journal of the American Medical Association, 271, 1788-1790.

Manson, J. E., Rimm, E. B., Colditz, G. A., Stampfer, M. J., Willett, W. C., Arky, R. A., Rosner, B., Hennekens, C. H. \& Speizer, F. E. (1992). Parity and incidence of non-insulin-dependent diabetes mellitus. American Joumal of Medicine 93, 13-18.

Martínez, H., Allen, L. H., Lung'aho, M., Chávez, A. \& Pelto, G. H. (1994). Maternal fatness in Mexican women predicts body composition changes in pregnancy and lactation. In Nutrient Regulation During Pregnancy, Lactation and Infant Growth, pp. 99-107 [L. Allen, J. King and B. Lönnerdal, editors]. New York: Plenum Press.

Meserole, L. P., Worthington-Roberts, B. S., Rees, J. M. \& Wright, L. S. (1984). Prenatal weight gain and postpartum weight loss in adolescents. Joumal of Adolescent Health Care 5, 21-27.

Millar, W. J. \& Stephens, T. (1987). The prevalence of overweight and obesity in Britain, Canada, and United States. American Journal of Public Health 77, 38-41.

Milne, A. C., McNeill, G. \& Zakary, A. (1991). Weight change as an indicator of energy imbalance during 7 day weighed food intake studies. Ecology of Food and Nutrition 26, 281-289.

Morse, E. H., Clarke, R. P., Merrow, S. B. \& Thibault, B. E. (1975). Comparison of the nutritional status of pregnant adolescents with adult pregnant women. II. Anthropometric and dietary findings. American Journal of Clinical Nutrition 28, 1422-1428. 
Mullins, A. (1960). Overweight in pregnancy. Lancet i, 146-147.

Murphy, S. P. \& Abrams, B. F. (1993). Changes in energy intakes during pregnancy and lactation in a national sample of United States women. American Joumal of Public Health 83, 1161-1163.

National Dairy Council (1994). Maternal and Fetal Nutrition. Fact File 11. London: National Dairy Council.

National Institutes of Health Consensus Development Panel on the Health Implications of Obesity (1985). Health implications of obesity. Annals of Internal Medicine 103, 1073-1077.

Newcombe, R. G. (1982). Development of obesity in parous women. Journal of Epidemiology and Community Health 36, 306-309.

Noppa. H. \& Bengtsson, C. (1980). Obesity in relation to socioeconomic status. A population study of women in Götenborg, Sweden. Joumal of Epidemiology and Community Health 34, 139-142.

Öhlin, A. \& Rössner, S. (1990). Maternal body weight development after pregnancy. International Journal of Obesity 14, $159-173$

Öhlin, A. \& Rössner, S. (1994). Trends in eating patterns, physical activity and socio-demographic factors in relation to postpartum body weight development. British Journal of Nutrition 71, 457-470.

Olsen, L. C. \& Mundt, M. H. (1986). Postpartum weight loss in a nurse-midwifery practice. Joumal of Nurse Midwifery 31, 177-181.

Orr, R. D. \& Simmons, J. J. (1979). Nutritional care in pregnancy: the patient's view. I-III. Joumal of the American Dietetic Association 75, 126-140.

Palmer, J. L., Jennings, G. E. \& Massey, L. (1985). Development of an assessment form: attitude toward weight gain during pregnancy. Journal of the American Dietetic Association 85, 946-949.

Palta, M., Prineas, R. J., Berman, R. \& Hannan, P. (1982). Comparison of self-reported and measured height and weight. American Journal of Epidemiology 115, 223-230.

Parham, E. S., Astrom, M. F. \& King, S. H. (1990). The association of pregnancy weight gain with the mother's postpartum weight. Journal of the American Medical Association 90, 550-554.

Parker, J. D. \& Abrams, B. A. (1993). Differences in postpartum weight retention between black and white mothers. Obstetrics and Gynecology 81, 768-774.

Perri, M. G., Nezu, A. M. \& Viegener, B. J. (1992). Improving the Long Term Management of Obesity: theory, research, and clinical guidelines. New York: John Wiley and Sons.

Piers, L. S., Diggavi, S. N., Thangam, S., Van Raaij, J. M. A., Shetty, P. S. \& Hautvast, J. G. A. J. (1995). Changes in energy expenditure, anthropometry, and energy intake during the course of pregnancy and lactation in well-nourished Indian women. American Journal of Clinical Nutrition 61, 501-513.

Pipe, N. G. J., Smith, T., Halliday, D., Edmonds, C. J., Williams, C. \& Coltart, T. M. (1979). Changes in fat, fat-free mass and body water in human normal pregnancy. British Joumal of Obstetrics and Gynaecology 86, 929-940.

Plass, E. D. \& Yoakam, W. A. (1929). Basal metabolism studies in normal pregnant women with normal and pathologic thyroid glands. Transactions of the American Gynecological Society 54, 165-177.

Poppitt, S. D., Prentice, A. M., Goldberg. G. R. \& Whitehead, R. G. (1994). Energy-sparing strategies to protect human fetal growth. American Journal of Obstetrics and Gynecology 171, 118-125.

Poppitt, S. D., Prentice, A. M., Jéquier, E., Schutz, Y. \& Whitehead, R. G. (1993). Evidence of energy sparing in Gambian women during pregnancy. A longitudinal study using whole-body calorimetry. American Joumal of Clinical Nutrition 57, 353-364.

Potter, S., Hannum, S., McFarlin, B., Essex-Sorlie, D., Campbell, E. \& Trupin, S. (1991). Does infant feeding method influence matemal postpartum weight loss? Journal of the American Dietetic Association 91, 441-446.

Prentice, A. M., Cole, T. J., Foord, F. A., Lamb, W. H. \& Whitehead, R. G. (1987). Increased birthweight after prenatal dietary supplementation of rural African women. American Journal of Clinical Nutrition 46, 912-925.

Prentice, A. M., Goldberg, G. R., Davies, H. L., Murgatroyd, P. R. \& Scott, W. (1989). Energy-sparing adaptations in human pregnancy assessed by whole-body calorimetry. British Joumal of Nutrition 62, 5-22.

Prentice, A. M., Whitehead, R. G., Roberts, S. B. \& Paul, A. A. (1981). Long-term energy balance in child-bearing Gambian women. American Joumal of Clinical Nutrition 34, 2790-2799.

Quandt, S. A. (1983). Changes in maternal postpartum adiposity and infant feeding patterns. American Joumal of Physical Anthropology 60, 455-461.

Rodin, J., Radke-Sharpe, N., Rebuffé-Scrive, M. \& Greenwood, M. R. C. (1990). Weight cycling and fat distribution. International Joumal of Obesity 14, 303-310.

Rona, R. J. \& Morris, R. W. (1982). National study of health and growth: social and family factors and overweight in English and Scottish parents. Annals of Human Biology 9, 147-156.

Rookus, M. A., Rokebrand, P., Burema, J. \& Deurenberg, P. (1987). The effect of pregnancy on the body mass index 9 months postpartum in 49 women. International Joumal of Obesity 11, 609-618.

Rössner, S. (1992). Pregnancy, weight cycling and weight gain in obesity. International Journal of Obesity 16, 145-147.

Rössner, S. \& Öhlin, A. (1995). Pregnancy as a risk factor for obesity. Lessons from the Stockholm pregnancy and weight development study. Obesity Research 3, 267s-275s.

Rosso, P. (1987). Regulation of food intake during pregnancy and lactation. Annals of the New York Academy of Sciences 499, 191-196.

Rutishauser, 1. H. E. \& Carlin, J. B. (1992). Body mass index and duration of breast feeding. A survival analysis during the first six months of life. Journal of Epidemiology and Community Health 46, 559-565. 
Sadurskis, A., Kabir, N., Wager, J. \& Forsum, E. (1988). Energy metabolism, body composition, and milk production in healthy Swedish women during lactation. American Joumal of Clinical Nutrition 48, 44-49.

Samra, J. S., Tang, L. C. H. \& Obhrai, M. S. (1988). Changes in body weight between consecutive pregnancies. Lancet ii, $1420-1421$.

Schauberger, C. W., Rooney, B. L. \& Brimer, L. M. (1992). Factors that influence weight loss in the puerperium. Obstetrics and Gynecology 79, 424-429.

Scholl, T. O., Hediger, M. L., Schall, J. I., Ances, I. G. \& Smith, W. K. (1995). Gestational weight gain, pregnancy outcome and postpartum weight retention. Obstetrics and Gynecology 86, 423-427.

Scholl, T. O., Hediger, M. L., Cronk, C. E. \& Schall, J. I. (1993). Maternal growth during pregnancy and lactation. Hormone Research 39 (Suppl. 3), 59-67.

Scholl, T. O., Hediger, M. L., Schall, J. I., Khoo, C-S. \& Fischer, R. L. (1994). Maternal growth during pregnancy and the competition for nutrients. American Joumal of Clinical Nutrition 60, 183-188.

Scott, J. A. \& Benjamin, B. (1948). Weight changes in pregnancy, Lancet 254, 550-551.

Segel, J. S. \& McAnarney, E. R. (1994). Adolescent pregnancy and subsequent obesity in African-American Girls. Journal of Adolescent Health 15, 491-494.

Sheldon, J. H. (1949). Maternal obesity. Lancet 257, 869-873.

Sikorski, J., Wilson, J., Clement, S., Das, S. \& Smeeton, N. (1996). A randomised controlled trial comparing two schedules of antenatal visits: the antenatal care project. British Medical Joumal 312, 546-553.

Singh, N. S., Singh, T. D., Singh, N. J. \& Bhattacharyya, S. K. (1983). Weight pattern in puerperium. Journal of the Indian Medical Association 81, 121-123.

Sinnathuray, T. A. \& Wong, W. P. (1972). Physiological weight changes in pregnancy in Malaysian women. Australian and New Zealand Journal of Obstetrics and Gynaecology 12, 122-125.

Smith, D. E., Lewis, C. E., Caveny, J. L., Perkins, L. L., Burke, G. L. \& Bild, D. E. (1994). Longitudinal changes in adiposity associated with pregnancy. Journal of the American Medical Association 271, 1747-1751.

Sohlström, A. \& Forsum, E. (1995). Changes in adipose tissue volume and distribution during reproduction in Swedish women as assessed by magnetic resonance imaging. American Journal of Clinical Nutrition 61, 287-295.

Sørensen, T. 1. A. \& Stunkard, A. J. (1993). Does obesity run in families because of genes? An adoption study using silhouettes as a measure of obesity. Acta Psychiatrica Scandinavica Suppl. 370, 67-72.

South-Paul, J. E., Rajagopal, K. R. \& Tenholder, M. F. (1992). Exercise responses prior to pregnancy and in the postpartum state. Medicine and Science in Sports and Exercise 24, 410-414.

Sowers, M-F., Crutchfield, M., Jannausch, M. L. \& Russell-Aulet, M. (1996). Longitudinal changes in body composition in women approaching the midlife. Annals of Human Biology 23, 253-265.

Stander, H. J. \& Pastore, J. B. (1940). Weight changes during pregnancy and puerperium. American Journal of Obstetrics and Gynecology 39, 928-937.

Stevens-Simon, C. \& McAnarney, E. R. (1992). Adolescent pregnancy. Gestational weight gain and maternal and infant outcomes. American Journal of Diseases of Children 146, 1359-1364.

Stevens-Simon, C., Roghmann, K. J. \& McAnamey, E. R. (1992). Relationship of self-reported pre-pregnant weight \& weight gain during pregnancy to maternal body habitus and age. Joumal of the American Dietetic Association 92 , 85-86.

Stewart, A. L. (1982). The reliability and validity of self-reported weight and height. Joumal of Chronic Diseases 35 , 295-309.

Strang, V. R. \& Sullivan, P. L. (1985). Body image attitudes during pregnancy and the postpartum period. Journal of Obstetrics and Neonatal Nursing 14, 332-337.

Taggart, N. R., Holliday, R. M., Billewicz, W. Z., Hytten, F. E. \& Thomson, A. M. (1967). Changes in skinfolds during pregnancy. British Joumal of Nutrition 21, 439-451.

Taylor, E. S. (1971). Beck's Obstetrical Practice, 9th edn. Baltimore, MD: Williams and Wilkins.

Thomson, A. M. \& Billewicz, W. Z. (1965). Maternal weight for height. Proceedings of the Nutrition Society 24, XIX-XX.

Thomson, A. M., Billewicz, W. Z., Thomson, B. \& McGregor, I. A. (1966). Body weight changes during pregnancy and lactation in rural African (Gambian) women. Journal of Obstetrics and Gynaecology of the British Commonwealth 73, 724-733

United States Department of Agriculture (1941). Women's measurements for garment and pattern construction. USDA Miscellaneous Publication no. 454.

United States Institute of Medicine (1990). Nutrition during Pregnancy. Washington, DC: National Academy Press.

Van Loan, M. D., Kopp, L. E., King, J. C., Wong, W. W. \& Mayclin, P. L. (1995). Fluid changes during pregnancy: use of bioimpedance spectroscopy. Journal of Applied Physiology 78, 1037-1042.

van Raaij, J. M. A., Peek, M. E. M., Vermaat-Miedema, S. H., Schonk, C. M. \& Hautvast, J. G. A. J. (1988). New equations for estimating body fat mass in pregnancy from body density or total body water. American Joumal of Clinical Nutrition 48, 24-29.

van Raaij, J. M. A., Schonk, C. M., Vermaat-Miedema, S. H., Peek, M. E. M. \& Hautvast, J. G. A. J. (1989). Body fat mass and basal metabolic rate in Dutch women before, during and after pregnancy: a reappraisal of energy cost of pregnancy. American Journal of Clinical Nutrition 49, 765-772. 
van Raaij, J. M. A., Schonk, C. M., Vermaat-Miedema, S. H., Peek, M. E. M. \& Hautvast, J. G. A. J. (1990). Energy cost of physical activity throughout pregnancy and the first year postpartum in Dutch women with sedentary lifestyles. American Journal of Clinical Nutrition 52, 234-239.

van Raaij, J. M. A., Vermaat-Miedema, S. H., Schonk, C. M., Peek, M. E. M. \& Hautvast, J. G. A. J. (1987). Energy requirements of pregnancy in the Netherlands. Lancet ii, 953-955.

Waters, E. G. (1942). Weight studies in pregnancy. American Journal of Obstetrics and Gynecology 43, 826832.

Weiss, W., Jackson, E. C., Niswander, K. \& Eastman, N. J. (1969). The influence on birthweight of change in maternal weight gain in successive pregnancies in the same woman. International Journal of Gynecology and Obstetrics 7 , $210-233$.

Whitehead, R. G., Lawrence, M. \& Prentice, A. M. (1986). Maternal nutrition and breast feeding. Human Nutrition Applied Nutrition 40A, Suppl. 1, 1-10.

Williamson, D. F., Madans, J., Anda, R. F., Kleinman, J. C., Giovino, G. A. \& Byers, T. (1991). Smoking cessation and severity of weight gain in a national cohort. New England Journal of Medicine 324, 739-745.

Williamson, D. F., Madans, J., Pamuk, E., Flegal, K. M., Kendrick, J. S. \& Serdula, M. K. (1994). A prospective study of childbearing and 10-year weight gain in US white women 25 to 45 years of age. International Journal of Obesity $18,561-569$.

Winkvist, A., Rasmussen, K. M. \& Habicht, J-P. (1992). A new definition of maternal depletion syndrome. American Journal of Public Health 82, 691-694.

Yamagishi, E., Kitade, K., Murakami, M. \& Hosoki, M. (1990). Factors affecting weight gain during normal pregnancy. In A Midwife's Gift: love, skill and knowledge: Proceedings of the International Conference of Midwifery 22. 324-327.

Zaadstra, B. M., Seidell, J. C., Van Noord, P. A. H., te Velde, E. R., Habberna, J. D. F., Vrieswijk, B. \& Karbaat, J. (1993). Fat and female fecundity: prospective study of effect of body fat distribution on conception rates. British Medical Journal 306, 484-487. 